\title{
Article \\ Antioxidant Capacity and Nutritional Value of Potato Tubers (Solanum tuberosum L.) as a Dependence of Growing Conditions and Long-Term Storage
}

\author{
Dorota Wichrowska $\mathbb{D}$
}

Citation: Wichrowska, D. Antioxidant Capacity and Nutritional Value of Potato Tubers (Solanum tuberosum L.) as a Dependence of Growing Conditions and Long-Term Storage. Agriculture 2022, 12, 21. https://doi.org/10.3390/ agriculture12010021

Academic Editor: Guodong Liu

Received: 16 November 2021

Accepted: 23 December 2021

Published: 25 December 2021

Publisher's Note: MDPI stays neutral with regard to jurisdictional claims in published maps and institutional affiliations.

Copyright: (C) 2021 by the author. Licensee MDPI, Basel, Switzerland. This article is an open access article distributed under the terms and conditions of the Creative Commons Attribution (CC BY) license (https:// creativecommons.org/licenses/by/ $4.0 /)$.
Department of Microbiology and Food Technology, Faculty of Agriculture and Biotechnology, Bydgoszcz University of Science and Technology, Kaliskiego 7 str., 85-796 Bydgoszcz, Poland; wichrowska@pbs.edu.pl

\begin{abstract}
The aim of the study was to assess the interactive effect of the use of bio-fertilizer and organic matter brought into the soil, as well as to limit the use of mineral fertilization on the content of bioactive compounds in potato tubers cultivar 'Satina'. The test results show a positive effect of the applied bio-fertilizer in all tested variants of organic fertilization (straw, fodder pea, manure) on the level of the tested compounds. Comparing the content of crude protein in tubers from plots where half the dose of mineral fertilization was applied, the use of bio-fertilizer increased the content of this component, especially after using straw. After 6 months of storage, organic fertilization had no significant effect on the protein content, while significant differences were found in tubers fertilized with mineral, in favor of the full dose of NPK fertilizers. The storage time increased the content of tyrosine, leucine, lysine, alanine, glutamic acid, and total AA, and also methionine, aspartic acid, and asparagine, while the content of isoleucine and phenyl-alanine decreased. The highest content of total polyphenols was found in tubers where the plots were covered with pea application, a full dose of mineral fertilizer, and the use of bio-fertilizer. Unfortunately, after 6 months of storage, potato tubers from plots fertilized with peas, especially those fertilized with half the dose of mineral fertilization and without the use of biofertilizer, significantly lost the most total polyphenols. Similar relationships were obtained for the level of chlorogenic acid in tubers, which is significantly correlated with the content of polyphenols, but only organic fertilization in the form of peas significantly increased the concentration of chlorogenic acid. On the other hand, the highest post-harvest antioxidant activity was characteristic of tubers from plots fertilized with manure, with a full dose of mineral fertilization and biofertilizer. During the 6-month storage, there was a decrease in the antioxidant capacity, on average $12.4 \%$ for the objects. This may indicate the influence of polyphenolic compounds as well as other antioxidants on the assessed trait.
\end{abstract}

Keywords: organic matter; bio-fertilizer; free amino acids; FRAP; polyphenols; chlorogenic acid; storage

\section{Introduction}

Sustainable development strategy aims to ensure ecological, economic, and social balance. According to these guidelines, agriculture should counteract natural degradation resources while maintaining all its functions. Good agricultural practices are one of the instruments combining the ecological and productive functions of agriculture [1]. Moreover, the idea of protecting biodiversity, the natural environment, and the consumer is becoming more and more popular and leads to the search for various methods of growing plants while reducing the pressure on the surrounding natural environment [2,3]. By 2050, the world population is predicted to reach 9.7 billion people. According to the Food and Agriculture Organization of the United Nations (FAO 2018) [4], food production will increase by $40-50$ percent depending on the degree of sustainability. This increase in agricultural production will have huge consequences in terms of land degradation, use of natural resources and greenhouse gas emissions. Potatoes are one of the most important 
crops in the world. It has a low carbon footprint and requires less land use than many other fruits, vegetables, and grains, giving most of the nutrients people need. It has an industrial, fodder, and also crop rotation importance [5].

Potatoes have been eaten for a long time, but research into their nutritional importance has increased their importance as alternatives to both food and nutritional security [6]. Availability per capita and the global trend in potato production indicate its decline in developed countries and accelerated growth in developing countries, including Asia and Africa. These two regions of the world also have a greater number of undernourished people, therefore the higher availability of potatoes per capita in these regions may justify the food and nutritional needs of the population [6]. Nutritionists claim that the nutritional value of the potato is so great that it may be the only human food for some time, without detriment to health [7]. The nutritional value of potato tubers is influenced by the content of essential amino acids (especially lysine), high starch and dietary fiber content, and low fat concentration [6-9]. Potato tubers, due to the amount of consumption (according to FAOSTAT is $32.3 \mathrm{~kg}$ per capita in the World) [10], are also a source of bioactive compounds and antioxidants [11-13], including phenolic acids (mainly chlorogenic acid), content from 49 to $1400 \mathrm{mg} \mathrm{kg}^{-1} \mathrm{DM}[14,15]$ and ascorbic acid [16-18]), which help to reduce the risk of many diseases such as cardiovascular disease by reducing cholesterol, inflammatory pathways, and cancer [19-23]. Increased consumption of potato tubers can increase blood and tissue antioxidant levels, counteracting oxidative stress, which is responsible for damage to lipids, proteins, enzymes, and DNA, causing chronic diseases such as cancer and cardiovascular diseases [12,15,21,24-27]. However, it is worth remembering that the potato tubers are eaten only after heat treatment (steaming, sous vide, boiling, frying). All technological processes reduce the content of antioxidants, especially vitamin C, by up to $63.90 \%$ [28]. Research into cooking procedures can help reduce oxidative and enzymatic degradation of vitamin $C$, and the most beneficial method for preserving antioxidants is sous vide [29].

In addition to being valuable for human health, potatoes are the main root crop for crop rotation, especially in organic farming, and allows for the management of weaker soil (light soils) [30,31]. In ecological crops or with limited use of agrotechnical treatments, a very important factor is the appropriate selection of potato cultivars, which should be as resistant to viral, bacterial, and fungal diseases as possible [31].

The growth of potato plants should be intense to be competitive with weeds in order to reduce the use of herbicide treatments [32]. The use of composting flora may be one of the most important sources of soil regeneration, and such opportunities are provided by the use of the UGmax soil fertilizer [33-36]. It is a vaccine of various microorganisms such as yeast, lactic acid bacteria (Pseudomonas, Actinobacteria, and Azotobacter), and small amounts of micro- and macronutrients, and in favorable climatic conditions, it can accelerate the decomposition of humus, crop residues, and organic fertilizers, mobilize nutrients from minerals or insoluble compounds, restore a better soil structure, improve water relations, and affect growth potato yields [37]. The results of previous research and information from agricultural practice, although often ambiguous or even contradictory, allowed for a hypothesis that the use of bio-fertilizers is a way to achieve biological balance in the agroecosystem, especially in the soil environment. The activity of microorganisms depends on the method, amount, and type of organic matter, which is a source of energy, brought into the soil. On the other hand, it should result in limiting the development of pests, which, in combination with the beneficial comprehensive influence on soil properties and resistance of crops to biotic and abiotic stress factors, creates conditions for obtaining high and good-quality crops with limited inputs of industrial means of production $[38,39]$.

At the same time, consumers are interested in so-called organic food, due to the information about its higher nutritional value. Unfortunately, it is not always confirmed in scientific research, hence it seemed interesting to undertake this study, the assumption of which was the possibility of limiting mineral fertilization through the use of bio-fertilizer and organic matter, as well as its impact on improving the conditions of plant growth and 
development, which would result in better crop quality. In addition, during long-term storage of potato tubers, natural losses occur due to respiration and water evaporation or pathogens. It is accompanied by weight loss and biochemical changes, the size of which depends on many factors. With the expiration of the storage period, weight losses may increase due to the germination of potato tubers. Taking into account the above issues, studies were carried out to assess the interaction effect of the application of bio-fertilizer and organic matter brought into the soil, as well as limiting the use of mineral fertilization on the content of bioactive compounds in potato tubers, such as the content of protein, chlorogenic acid, total polyphenols, antioxidant capacity (FRAP), and amino acid content after harvest and storage.

\section{Materials and Methods}

\subsection{Experimental Location and Treatment}

The experimental location and treatment are described in detail in manuscript by Wichrowska and Szczepanek [40].

Strict tests in field conditions and in a storage facility were carried out in the years 2009-2011. The field experiment was established at the Faculty Research Station of Agriculture and Biotechnology of the University of Technology and Life Sciences in Mochełek $\left(53^{\circ} 13^{\prime} \mathrm{N}, 17^{\circ} 51^{\prime} \mathrm{E}\right)$. The period of storage of potato tubers was 6 months in controlled chambers. The research material was a medium-early potato (Solanum tuberosum L.) cultivar 'Satina'. The field experiment was established on lessive soil, made of order clay classified as a good rye complex, class IVb, on plots with an area of $31.5 \mathrm{~m}^{2}$ in three replications, as a 3-factor: 1st factor-organic matter brought into the soil, 2nd factor-rate of mineral fertilization (ammonium nitrate $34 \%$, triple superphosphate $46 \%$, potassium sulphate $50 \%$ ): $100 \%$ NPK-100 kg N ha ${ }^{-1}, 100 \mathrm{~kg} \mathrm{P}_{2} \mathrm{O}_{5} \mathrm{ha}^{-1}, 150 \mathrm{~kg} \mathrm{~K}_{2} \mathrm{O} \mathrm{ha}^{-1}$ or $50 \%$ NPK— $50 \mathrm{~kg} \mathrm{~N} \mathrm{ha}^{-1}, 50 \mathrm{~kg} \mathrm{P}_{2} \mathrm{O}_{5} \mathrm{ha}^{-1}, 150 \mathrm{~kg} \mathrm{~K}_{2} \mathrm{O} \mathrm{ha}^{-1}$ ), 3rd factor-application of the UGmax soil fertilizer. In the spring, before planting the potatoes, mineral fertilizers were applied in doses that took into account the fertility of the soil (high phosphorus content and medium-low potassium content) and the nutritional requirements of the plants. The condition of the soil was measured every year. The chemical composition of soil before the start of the field experiment in the years analyzed was similar; it demonstrated a very low richness in available forms of magnesium and also a low amount of available nitrogen [40].

As organic matter in each year of research, FYM at a dose of $25 \mathrm{t} \cdot \mathrm{ha}^{-1}$, straw $-4 \mathrm{t} \cdot \mathrm{ha}^{-1}$, and catch crop (fodder pea) at the dose of $27 \mathrm{t} \cdot \mathrm{ha}^{-1}$ was used for plowing in winter. The soil fertilizer UGmax was applied each year in two doses soil: $0.6 \mathrm{~L} \cdot \mathrm{ha}^{-1}$ in the fall before plowing in winter for organic matter and $0.3 \mathrm{~L} \cdot \mathrm{ha}^{-1}$ in spring, before planting tubers. Additionally, $0.3 \mathrm{~L} \cdot \mathrm{ha}^{-1}$ was applied in foliage at a plant height of $15-20 \mathrm{~cm}$. In the control combination, the potato was grown without organic fertilization and without soil biofertilizer. The UGmax bio-fertilizer is a microbiological preparation which consists of yeast, Lactobacillus, Lactococcus, Pseudomonas, Actinobacteria, and Azotobacteras, as well as potassium $3.5 \mathrm{~g} \mathrm{dm}^{-3}$, nitrogen $1.2 \mathrm{~g} \mathrm{dm}^{-3}$, sulfur $1.0 \mathrm{~g} \mathrm{dm}^{-3}$, phosphorus $0.5 \mathrm{~g} \mathrm{dm}^{-3}$, sodium $0.2 \mathrm{~g} \mathrm{dm}^{-3}$, magnesium $0.1 \mathrm{~g} \mathrm{dm}^{-3}$, zinc $0.02 \mathrm{~g} \mathrm{dm}^{-3}$, and manganese $0.003 \mathrm{~g} \mathrm{dm}^{-3}$.

\subsection{Plant Sampling}

Immediately after harvest, potato tubers were transferred to the storage chamber at a temperature of $6{ }^{\circ} \mathrm{C}$ and $80 \%$ relative air humidity, and then a representative sample was prepared for analysis before and after 6 months of storage. The tubers were cut and frozen in liquid nitrogen and stored at the temperature of at least $-18{ }^{\circ} \mathrm{C}$ for further studies. The frozen material was lyophilized (model Alpha 1-4 LDplus, Donserv, Warszawa, Poland), then ground into a fine powder (the particles $0.3-0.5 \mathrm{~mm}$ in size) using the ultracentrifuge Retsch mill ZM 100 (Retsch, Haan, Germany). The ground samples were stored in the dark in bags which were placed in desiccators for further analysis. 


\subsection{The Laboratory Analyses}

The laboratory analyses (nitrogen content, amino acids, total polyphenols, chlorogenic acid, antioxidant potential FRAP) were carried out at the Department of Quality Plant Products in the Georg August University in Göttingen and Department of Microbiology and Food Technology in Bydgoszcz University of Science and Technology. The content of crude protein was determined by multiplying the total nitrogen by factor 6.25 , with the Kjeldahl method using Büchi Labortechnik B-324 apparatus, after mineralization in concentrated sulphuric acid (VI). The total nitrogen was analyzed following to the Dumas combustion method by LECO CN-2000 [41]. Free amino acids were extracted from freeze-dried potato flour using hydrochloric acid as described by Fischer et al. [42]. A $0.5 \mathrm{~g}$ portion of freezedried potato flour was suspended in a centrifuge tube with $4 \mathrm{~mL} 1 \mathrm{~N}$ hydrochloric acid. The tube was shaken horizontally for $1 \mathrm{~h}$ and centrifuged at $15,000 \times \mathrm{g}$ relative centrifugal force (RCF) for $30 \mathrm{~min}$. The supernatant was collected in a $10 \mathrm{~mL}$ volumetric flask. The extraction was performed three times, with the last two extractions being with $3 \mathrm{~mL}$ of hydrochloric acid. Finally, the hydrochloric acid was added to the flask to adjust the final $10 \mathrm{~mL}$. To get a clear solution, the supernatant was centrifuged again at $15,000 \times g$ RFC for $30 \mathrm{~min}$. Free amino acids were assayed using HPLC. The HPLC system consists of degasser WellChrom K-5004 (Knauer, Berlin, Germany), multisolvent delivery system 600 E (Waters, Milford, MA, USA), autosampler 2157 (Parmacia LKB, Uppsala, Sweden), the temperature control module (Waters, USA), $5 \mu \mathrm{m}$ column LiChroCart 250-3 and pre-column LiChroCart 4-4 (Merc, Stuttgart, Germany), and fluorescens detector 474 (Waters, USA). The gradient eluents, which consisted of methanol $(71 / 29$ and $20 / 80, v / v)$ in $50 \mathrm{mM}$ sodium acetate buffer ( $\mathrm{pH} 7.0$ ), were used to separate the amino acids at the flow rate of $0.6 \mathrm{~mL} \mathrm{~min}^{-1}$ and the temperature of $45^{\circ} \mathrm{C}$. The amino acids were standardized using the Perbio Amino Acid Standard H (USA). The HPLC separation of fluorescent o-phtaldialdehyde (OPA) derivatives was applied to the assay of free amino acids according to the method described by Fischer et al. [36]. The procedure was based on the reaction of reducing agent $\beta$-mercaptoethanol, to give a complex which can be measured by fluorescence. The OPA solution was prepared by dissolving $125 \mathrm{mg}$ of OPA in $22 \mathrm{~mL}$ of methanol, then mixing it with $500 \mu \mathrm{L}$ of $\beta$-mercaptoethanol and $2.5 \mathrm{~mL} 0.5 \mathrm{M}$ borate buffer at $\mathrm{pH}$ 9.5. The extract of amino acids was derived with the fluorescens reagent (o-phtaldialdehyde) for two min. The microliters of the mixture were injected into the HPLC. In this publication, mean of the factors of amino-acids content after harvest is presented to compare with the results after 6 months of storage. All of the results after harvest are described by Wichrowska and Szczepanek [40]. Chlorogenic acid was determined spectrophotometrically according to Griffith et al. [43]. Freeze-dried potato flour $(100 \mathrm{mg})$ was suspended in $2 \mathrm{~mL}$ solution consisting of $0.17 \mathrm{M}$ urea (Merck, Darmstadt, Germany) and 0.1 acetic acid (Merck, Darmstadt, Germany). After adding $1 \mathrm{~mL}$ distilled water, the suspension was shaken for $15 \mathrm{~s}$. After shaking, $1 \mathrm{~mL} 0.014 \mathrm{M}$ natrium nitrate (Merck, Darmstadt, Germany) was added and mixed well. After two min of reaction, $1 \mathrm{~mL} \mathrm{0.5} \mathrm{M} \mathrm{natriumhydroxid} \mathrm{(Carl-Roth,} \mathrm{Karlsruhe,}$ Germany) was added to the suspension. The suspension was then centrifuged at $2250 \times g$ $\mathrm{RCF}$ in a centrifuge for $10 \mathrm{~min}$. The absorbance of the clear solution was measured at $510 \mathrm{~nm}$ with a spectrophotometer (UV-1800 Spectrophotometer System, Shimadzu, Kyoto, Japan). The concentration was calculated from the standard curve produced by measuring $50 \mathrm{ppm}$ to $400 \mathrm{ppm}$ of caffeic acid (Sigma-Aldrich, Darmstadt, Germany). Total phenolic content was determined using the Folin-Ciocalteu reagent (Sigma-Aldrich, Darmstadt, Germany) according to the method of Singleton and Orthofer [44]. A volume of $0.5 \mathrm{~mL}$ of Folin-Ciocalteu reagent previously diluted with distilled water (1:10) was mixed with $0.1 \mathrm{~mL}$ of each sample. The solution was allowed to stand for $5 \mathrm{~min}$ at $25^{\circ} \mathrm{C}$ before adding $1.7 \mathrm{~mL}$ of sodium carbonate solution ( $20 \%$ ). Then, $10 \mathrm{~mL}$ of distilled water was added to the mixture and the absorbance was measured at $\lambda=735 \mathrm{~nm}$ after $20 \mathrm{~min}$ of incubation with agitation at room temperature. Results were expressed in $\mathrm{mg}$ of gallic acid equivalents (GAE) per $\mathrm{kg}$ of fresh sample. The determination of the antioxidant capacity by the FRAP method was conducted using the method developed by Benzie and Strein [45]. 
Immediately prior to the assay, a FRAP working solution was prepared: $250 \mathrm{~mL}$ of acetate buffer with pH of 3.6 (Sigma-Aldrich, Darmstadt, Germany), $25 \mathrm{~mL}$ of the TPTZ solution (2,4,6-Tri(2-pyridyl)-s-triazine) (Sigma-Aldrich, Darmstadt, Germany) (10 millimoles in $40 \mathrm{mmol} \mathrm{HCl})$, and $25 \mathrm{~mL}$ of an iron(III) chloride hexahydrate solution $(20 \mathrm{mmol})$ were mixed (Sigma-Aldrich, Darmstadt, Germany). The solution was incubated at $37^{\circ} \mathrm{C}$ and assays were then performed. Then, $6 \mathrm{~mL}$ of the FRAP solution was taken and $200 \mu \mathrm{L}$ of the sample and $600 \mu \mathrm{L}$ of $\mathrm{H}_{2} \mathrm{O}$ were added to it. After $4 \mathrm{~min}$ from the addition of the sample, absorbance was measured at a wavelength of $593 \mathrm{~nm}$. Based on the conducted measurements, a curve of dependence of the absorbance value on the juice concentration was plotted. Based on the curve, the absorbance value was determined at a concentration equal to the mean of the dilutions used and the antioxidant capacity was calculated at the same absorbance value based in the standard curve determined for $\mathrm{Fe}^{2+}$ iron ions. In order to remove solid parts, the samples were centrifuged for $5 \mathrm{~min}$ on a Rotina 420R centrifuge (Hettich, Vlotho, Germany) at $2250 \times g$ RCF prior to the assays.

\subsection{Statistical Analysis}

Field experiments were established in three years, 2009, 2011, and 2012, in a completely randomized design (CRD) with four replications. The quality assessment of potato tubers harvested in each year was performed just after harvest and after 6 months of storage. In Tables 1 and 10-13, multifactorial ANOVA was used in order to test the single effects of organic fertilization, mineral fertilization, and bio-fertilizer as well as for the interaction. The significance of differences (LSD_Lowest Significance Difference) was evaluated using the Tukey multiple confidence intervals for the significance level of $\alpha=0.05$ and 0.01 . In Tables 2-9, a Tukey post hoc test was employed with a significance level of $p \leq 0.05$. All the data from Tables 2-8 and Figures 1-4 were reported as the means with standard errors of the mean (SEM). All analyses were calculated using Statistica ${ }^{\circledR} 13.1$ software.

\section{Results}

\subsection{Total Protein Content in Potato Tubers after Harvest and after 6 Months of Storage}

Based on three years of research, the content of crude protein in the dry matter of edible potato tubers of the 'Satina' cultivar was determined. The effect of $100 \%$ mineral fertilization and the organic sources significantly increased the crude protein content in potato tubers. There are also positive interactions between all three factors (Table 1). In our study, the crude protein in tubers ranged between 99.1 and $114.4 \mathrm{~g} \mathrm{~kg}^{-1} \mathrm{DM}$ (Table 2). The highest content of crude protein in potato tubers was found after a combined application of green fertilizer (fodder pea) with a full rate of nitrogen, phosphorus, and potassium (NPK) and bio-fertilizer used. Based on a comparison of the content of crude protein in the tubers from the plots where half the rate of mineral fertilization was applied, the use of bio-fertilizer increased that component, especially after applying straw.

After 6 months of storage, organic fertilization did not have a significant effect on the protein content, while significant differences were found in tubers fertilized with mineral, in favor of the full dose of NPK fertilizers (Table 3). The use of bio-fertilizer also increased the protein content in potato tubers. There were no significant interactions between the studied factors (Table 1). The highest protein losses during storage were recorded in tubers from plots fertilized with half the NPK dose, without the use of organic fertilizers and biofertilizer, and they amounted to $9.06 \%$ (Figure 1), and the lowest losses occurred in tubers fertilized with manure with a full dose of mineral fertilizers and with the applied bio-fertilizer (1.44\%) (Figure 1). Highly significant interactions of the studied factors with storage time were also found (Table 3). In tubers from control plots and with a half of the dose of mineral fertilizer, as well as those fertilized with straw without the use of biofertilizer and mineral fertilization, the highest decrease in total protein content was noted (Table 4, Figure 1). 
Table 1. Bioactive compounds after harvest and storage. Significance of experimental factors and their interaction, mean from the 3 years of study.

\begin{tabular}{|c|c|c|c|c|c|c|c|}
\hline Bioactive Compounds & $\begin{array}{l}\text { Organic } \\
\text { Fertilizers }\end{array}$ & $\begin{array}{l}\text { Mineral } \\
\text { Fertilizers }\end{array}$ & $\begin{array}{c}\text { Bio- } \\
\text { Fertilizer }\end{array}$ & $\begin{array}{c}\text { Organic } \\
\text { Fertilizers } \\
\times \\
\text { Mineral } \\
\text { Fertilizers }\end{array}$ & $\begin{array}{c}\text { Organic } \\
\text { Fertilizers } \\
\times \\
\text { Bio- Fertilizer }\end{array}$ & $\begin{array}{c}\text { Mineral } \\
\text { Fertilizers } \\
\times \\
\text { Bio- Fertilizer }\end{array}$ & $\begin{array}{l}\text { Organic } \\
\text { Fertilizers } \\
\quad \times \\
\text { Mineral } \\
\text { Fertilizers } \\
\quad \times \\
\text { Bio- Fertilizer }\end{array}$ \\
\hline \multicolumn{8}{|c|}{ After harvest } \\
\hline Protein & n.s. & $* *$ & $* *$ & n.s. & n.s. & $* *$ & $* *$ \\
\hline Total polyphenols & $* *$ & $* *$ & $* *$ & $* *$ & $* *$ & $* *$ & $* *$ \\
\hline Chlorogenic acid & $* *$ & n.s. & n.s. & n.s. & n.s & n.s. & n.s \\
\hline Antioxidant potential FRAP & ** & $* *$ & $* *$ & $*$ & $*$ & $*$ & $* *$ \\
\hline \multicolumn{8}{|c|}{ After storage } \\
\hline Protein & n.s. & $* *$ & $* *$ & n.s. & n.s. & n.s. & n.s. \\
\hline Total polyphenols & $* *$ & $* *$ & $* *$ & $* *$ & $* *$ & $* *$ & $* *$ \\
\hline Chlorogenic acid & $* *$ & n.s. & n.s. & n.s. & n.s. & n.s. & n.s. \\
\hline Antioxidant potential FRAP & $* *$ & $* *$ & $* *$ & $*$ & $*$ & $* *$ & $* *$ \\
\hline \multirow{2}{*}{\multicolumn{8}{|c|}{$\begin{array}{l}\text { Multifactorial ANOVA was used in order to test the single effects of organic fertilization, mineral fertilization, } \\
\text { and bio-fertilizer as well as for the interaction. * significant difference } p \leq 0.05 ;{ }^{* *} \text { significant difference } p \leq 0.01 \text {; } \\
\text { n.s.-non-significant difference. } \\
\text { Table } 2 \text {. Total protein content in potato tubers after harvest depending on the applied research factors } \\
\text { (g. } \mathrm{kg}^{-1} \text { of dry weight) (mean from } 3 \text { years). }\end{array}$}} \\
\hline & & & & & & & \\
\hline & \multirow{2}{*}{\multicolumn{2}{|c|}{$\begin{array}{c}\text { Type of Organic } \\
\text { Fertilizer }\end{array}$}} & \multirow{2}{*}{\multicolumn{2}{|c|}{ Bio-Fertilizer Application }} & \multicolumn{2}{|c|}{$\begin{array}{c}\text { Mineral } \\
\text { NPK Fertilization }\end{array}$} & \multirow[t]{2}{*}{ Mean } \\
\hline & & & & & $100 \%$ & $50 \%$ & \\
\hline & \multicolumn{2}{|c|}{ Control } & \multicolumn{2}{|c|}{$\begin{array}{c}\text { Control } \\
\text { Bio-fertilizer }\end{array}$} & $\begin{array}{l}108.1 \pm 0.02 \\
110.9+0.04\end{array}$ & $\begin{array}{l}103.8 \pm 0.03 \\
104.4+0.04\end{array}$ & $\begin{array}{l}105.9 \\
1077\end{array}$ \\
\hline & \multirow{2}{*}{\multicolumn{2}{|c|}{$\begin{array}{l}\text { Catch crop } \\
\text { (fodder pea) }\end{array}$}} & \multirow{2}{*}{\multicolumn{2}{|c|}{$\begin{array}{c}\text { Control } \\
\text { Bio-fertilizer }\end{array}$}} & & 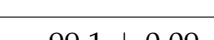 & 1050 \\
\hline & & & & & $\begin{array}{l}111.3 \pm 0.06 \\
114.4 \pm 0.01\end{array}$ & $\begin{array}{c}99.1 \pm 0.09 \\
102.8 \pm 0.04\end{array}$ & $\begin{array}{l}105.2 \\
108.6\end{array}$ \\
\hline & \multirow{2}{*}{\multicolumn{2}{|c|}{ Straw }} & \multirow{2}{*}{\multicolumn{2}{|c|}{$\begin{array}{c}\text { Control } \\
\text { Bio-fertilizer }\end{array}$}} & $111.4 \pm 0.02$ & $103.4 \pm 0.12$ & 107.4 \\
\hline & & & & & $112.5 \pm 0.04$ & $108.4 \pm 0.08$ & 110.5 \\
\hline & \multirow{2}{*}{\multicolumn{2}{|c|}{$\begin{array}{c}\text { Farmyard } \\
\text { manure (FYM) }\end{array}$}} & \multirow{2}{*}{\multicolumn{2}{|c|}{$\begin{array}{c}\text { Control } \\
\text { Bio-fertilizer }\end{array}$}} & $104.7 \pm 0.08$ & $100.3 \pm 0.04$ & 102.5 \\
\hline & & & & & $104.1 \pm 0.06$ & $104.1 \pm 0.06$ & 104.1 \\
\hline & \multirow{7}{*}{\multicolumn{2}{|c|}{ Mean }} & \multicolumn{2}{|c|}{ Control } & 109.5 & 104.1 & $106.8^{\mathrm{a}}$ \\
\hline & & & \multicolumn{2}{|c|}{ Catch crop (fodder pea) } & 112.9 & 112.9 & $100.9^{\text {a }}$ \\
\hline & & & \multicolumn{2}{|c|}{ Straw } & 112.8 & 112.0 & $105.9^{\mathrm{a}}$ \\
\hline & & & Farmyarc & anure (FYM) & 104.4 & 104.4 & $102.2^{\mathrm{a}}$ \\
\hline & & & \multicolumn{2}{|c|}{ Control } & 108.9 & 101.7 & $105.3^{\mathrm{B}}$ \\
\hline & & & \multicolumn{2}{|c|}{ Bio-fertilizer } & 110.5 & 104.9 & $107.7^{\mathrm{A}}$ \\
\hline & & & \multicolumn{2}{|c|}{$\begin{array}{c}\text { Mineral } \\
\text { NPK Fertilization }\end{array}$} & $109.7^{\mathrm{A}}$ & $103.3^{\mathrm{B}}$ & 106.5 \\
\hline
\end{tabular}

$\overline{\mathrm{a}, \mathrm{A}, \mathrm{B}}$ Means noted with the same letter in column and verse are not significantly different $(p<0.05)$.

Table 3. Effect of organic and mineral fertilization, bio-fertilizers, and storage on the bioactive compounds.

\begin{tabular}{|c|c|c|c|}
\hline Bioactive Compounds & $\begin{array}{c}\text { Organic Fertilizers } \\
\times \\
\text { Storage }\end{array}$ & $\begin{array}{c}\text { Mineral Fertilizers } \\
\times \\
\text { Storage }\end{array}$ & $\begin{array}{c}\text { Bio-Fertilizer } \\
\times \\
\text { Storage }\end{array}$ \\
\hline Protein & $* *(-)$ & $* *(-)$ & $* *(-)$ \\
\hline Total polyphenols & $* *(-)$ & $* *(-)$ & $* *(-)$ \\
\hline Chlorogenic acid & $* *(-)$ & n.s. & n.s. \\
\hline Antioxidant potential FRAP & $* *(-)$ & $* *(-)$ & $* *(-)$ \\
\hline
\end{tabular}

Explanation in a Table 1. 
Table 4. Total protein content in potato tubers after 6 months of storage depending on the applied research factors ( $\mathrm{g} \cdot \mathrm{kg}^{-1}$ of dry weight) (mean from 3 years).

\begin{tabular}{|c|c|c|c|c|}
\hline \multirow{2}{*}{$\begin{array}{c}\text { Type of Organic } \\
\text { Fertilizer }\end{array}$} & \multirow[t]{2}{*}{ Bio-Fertilizer Application } & \multicolumn{2}{|c|}{$\begin{array}{c}\text { Mineral } \\
\text { NPK Fertilization }\end{array}$} & \multirow[t]{2}{*}{ Mean } \\
\hline & & $100 \%$ & $50 \%$ & \\
\hline \multirow{2}{*}{ Control } & Control & $101.6 \pm 0.05$ & $94.4 \pm 0.08$ & 98.0 \\
\hline & Bio-fertilizer & $105.9 \pm 0.08$ & $98.8 \pm 0.07$ & 102.4 \\
\hline \multirow{2}{*}{$\begin{array}{l}\text { Catch crop } \\
\text { (fodder pea) }\end{array}$} & Control & $97.2 \pm 0.09$ & $96.1 \pm 0.09$ & 98.2 \\
\hline & Bio-fertilizer & $106.6 \pm 0.07$ & $98.6 \pm 0.08$ & 104.1 \\
\hline \multirow{2}{*}{ Straw } & Control & $99.4 \pm 0.09$ & $95.6 \pm 0.09$ & 97.5 \\
\hline & Bio-fertilizer & $106.9 \pm 0.09$ & $99.4 \pm 0.10$ & 103.2 \\
\hline \multirow{2}{*}{$\begin{array}{c}\text { Farmyard } \\
\text { manure (FYM) }\end{array}$} & Control & $102.4 \pm 0.11$ & $98.1 \pm 0.11$ & 103.8 \\
\hline & Bio-fertilizer & $102.6 \pm 0.09$ & $102.1 \pm 0.11$ & 103.3 \\
\hline \multirow{7}{*}{ Mean } & Control & 103.8 & 96.6 & $100.2^{\mathrm{a}}$ \\
\hline & Catch crop (fodder pea) & 101.9 & 97.4 & $101.2^{\mathrm{a}}$ \\
\hline & Straw & 103.2 & 97.5 & $100.4^{\mathrm{a}}$ \\
\hline & Farmyard manure (FYM) & 102.5 & 100.1 & $103.6^{\mathrm{a}}$ \\
\hline & Control & 100.2 & 96.1 & $99.4^{\mathrm{B}}$ \\
\hline & Bio-fertilizer & 105.5 & 99.7 & $103.3^{\mathrm{A}}$ \\
\hline & $\begin{array}{c}\text { Mineral } \\
\text { NPK Fertilization }\end{array}$ & $102.8^{\mathrm{A}}$ & $97.9^{\mathrm{B}}$ & 101.3 \\
\hline
\end{tabular}

a, A, B Means noted with the same letter in column and verse are not significantly different $(p<0.05)$.

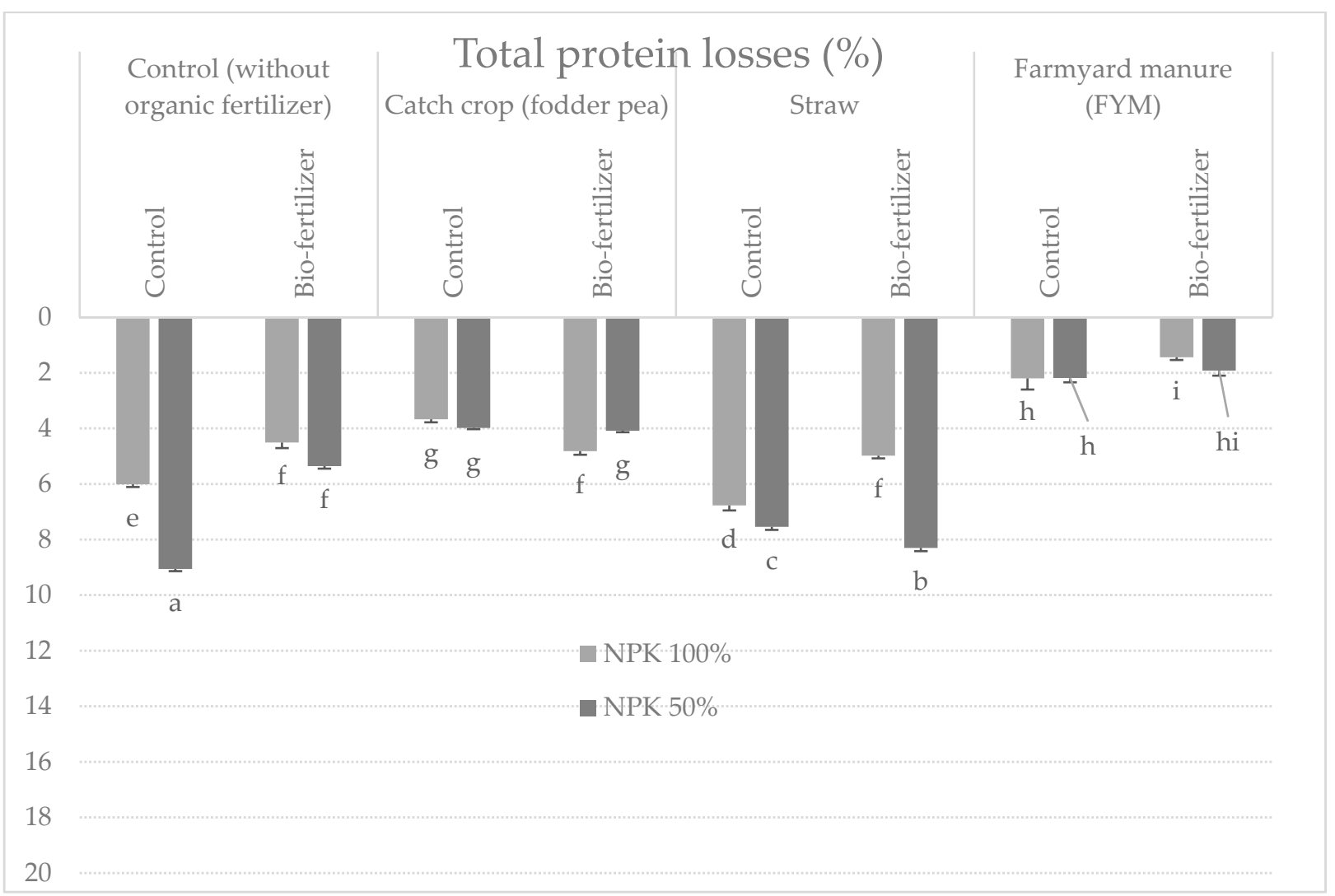

Figure 1. Percentage changes in total protein content in potato tubers after 6 months of storage depending on the tested factors $\left(\mathrm{g} \cdot \mathrm{kg}^{-1} \mathrm{DM}\right)$ (mean from 3 years storage seasons). $\mathrm{a}, \mathrm{b}, \mathrm{c}, \mathrm{d} \ldots$ : means noted with the same letter are not significantly different $(p<0.05)$. 


\subsection{Total Polyphenols Content in Potato Tubers after Harvest and after 6 Months of Storage}

The content of total polyphenols in potato tubers after harvest was significantly differentiated under the influence of the examined factors (Table 5). Fertilization with green fertilizer increased the tested trait in tubers, as did the full dose of NPK and the use of biofertilizer (Table 1). Significant interactions between the studied factors were also found (Table 1). The best set of factors for the examined feature was the application of peas, the full dose of mineral fertilizer, and the application of bio-fertilizer, both after harvest and after storage (Tables 5 and 6). Unfortunately, after 6 months of storage, potato tubers from plots fertilized with peas, especially those fertilized with half the dose of mineral fertilization, and without biofertilization, significantly lost the most total polyphenols (16.4\%) (Figure 2, Table 3).

\subsection{Chlorogenic Acid Content in Potato Tubers after Harvest and after 6 Months of Storage}

Various variants of using organic matter had a significant impact on the content of chlorogenic acid in potato tubers after harvesting (Tables 1 and 7). The highest content of chlorogenic acid was contained in samples from plots with the use of organic matter-peas (4.04 $\mathrm{g} \cdot \mathrm{kg}^{-1}$ of dry matter). The other examined factors did not significantly affect the value of the examined trait after harvest (Tables 1 and 7). After storage, the content of chlorogenic acid decreased on average for objects by $13.06 \%$ (Figure 2). In the samples tested after 6 months of storage, tubers from plots with pea and manure fertilization had the most significant amount of chlorogenic acid, and the least significant were tubers not fertilized with organic fertilization (Tables 1 and 8). However, in relation to the content after harvest, the largest losses of chlorogenic acid in tubers fertilized with peas were noted in relation to their content after harvest (Figure 3). Organic fertilization and storage time significantly modified the content of chlorogenic acid in potato tubers (Table 3).

Table 5. Total polyphenols content in potato tubers after harvest depending on the applied research factors (mg GAE kg-1 DM) (mean from 3 years).

\begin{tabular}{|c|c|c|c|c|}
\hline \multirow{2}{*}{$\begin{array}{c}\text { Type of Organic } \\
\text { Fertilizer }\end{array}$} & \multirow[t]{2}{*}{ Bio-Fertilizer Application } & \multicolumn{2}{|c|}{$\begin{array}{c}\text { Mineral } \\
\text { NPK Fertilization }\end{array}$} & \multirow[t]{2}{*}{ Mean } \\
\hline & & $100 \%$ & $50 \%$ & \\
\hline \multirow{2}{*}{ Control } & Control & $4.77 \pm 0.01$ & $4.68 \pm 0.01$ & 4.73 \\
\hline & Bio-fertilizer & $4.81 \pm 0.01$ & $4.72 \pm 0.02$ & 4.77 \\
\hline \multirow{2}{*}{$\begin{array}{l}\text { Catch crop } \\
\text { (fodder pea) }\end{array}$} & Control & $5.21 \pm 0.02$ & $4.89 \pm 0.01$ & 5.05 \\
\hline & Bio-fertilizer & $5.64 \pm 0.01$ & $5.06 \pm 0.01$ & 5.35 \\
\hline \multirow{2}{*}{ Straw } & Control & $4.35 \pm 0.01$ & $4.12 \pm 0.03$ & 4.24 \\
\hline & Bio-fertilizer & $4.58 \pm 0.02$ & $4.26 \pm 0.01$ & 4.42 \\
\hline \multirow{2}{*}{$\begin{array}{c}\text { Farmyard } \\
\text { manure (FYM) }\end{array}$} & Control & $4.81 \pm 0.03$ & $4.62 \pm 0.01$ & 4.72 \\
\hline & Bio-fertilizer & $4.98 \pm 0.00$ & $4.85 \pm 0.02$ & 4.92 \\
\hline \multirow{7}{*}{ Mean } & Control & 4.79 & 4.70 & $4.75^{c}$ \\
\hline & Catch crop (fodder pea) & 5.43 & 4.98 & $5.20^{a}$ \\
\hline & Straw & 4.47 & 4.19 & $4.33^{\mathrm{d}}$ \\
\hline & Farmyard manure (FYM) & 4.90 & 4.74 & $4.82^{b}$ \\
\hline & Control & 4.79 & 4.58 & $4.68^{\mathrm{B}}$ \\
\hline & Bio-fertilizer & 5.00 & 4.72 & $4.86^{\mathrm{A}}$ \\
\hline & $\begin{array}{c}\text { Mineral } \\
\text { NPK Fertilization }\end{array}$ & $4.89^{\mathrm{A}}$ & $4.65^{\mathrm{B}}$ & 4.77 \\
\hline
\end{tabular}

$\bar{a}, b, c, d, A, B$ Means noted with the same letter in column and verse are not significantly different $(p<0.05)$. 
Table 6. Total polyphenols content in potato tubers after 6 months of storage depending on the applied research factors ( $\left.\mathrm{g} \mathrm{GAE} \mathrm{kg}{ }^{-1} \mathrm{DM}\right)$ (mean from 3 years).

\begin{tabular}{ccccc}
\hline \multirow{2}{*}{$\begin{array}{c}\text { Type of Organic } \\
\text { Fertilizer }\end{array}$} & Bio-Fertilizer Application & \multicolumn{2}{c}{ Mineral } & \\
& & NPK Fertilization & Mean \\
\cline { 2 - 4 } Control & Control & $4.21 \pm 0.01$ & $4.03 \pm 0.01$ & 4.12 \\
& Bio-fertilizer & $4.25 \pm 0.01$ & $4.08 \pm 0.02$ & 4.17 \\
\hline Catch crop & Control & $4.54 \pm 0.02$ & $4.09 \pm 0.02$ & 4.32 \\
(fodder pea) & Bio-fertilizer & $4.75 \pm 0.01$ & $4.24 \pm 0.02$ & 4.50 \\
\hline \multirow{2}{*}{ Straw } & Control & $3.89 \pm 0.01$ & $3.65 \pm 0.03$ & 3.77 \\
& Bio-fertilizer & $3.97 \pm 0.02$ & $3.85 \pm 0.01$ & 3.91 \\
\hline Farmyard & Control & $4.22 \pm 0.01$ & $4.01 \pm 0.01$ & 4.12 \\
manure (FYM) & Bio-fertilizer & $4.27 \pm 0.01$ & $4.15 \pm 0.01$ & 4.21 \\
\hline \multirow{2}{*}{ Mean } & Control & 4.23 & 4.06 & $4.14^{\mathrm{b}}$ \\
& Catch crop (fodder pea) & 4.65 & 4.17 & $4.41^{\mathrm{a}}$ \\
& Straw & 3.93 & 3.75 & $3.84^{\mathrm{c}}$ \\
& Farmyard manure (FYM) & 4.25 & 4.08 & $4.16^{\mathrm{b}}$ \\
\cline { 2 - 4 } & Control & 4.22 & 3.95 & $4.08^{\mathrm{B}}$ \\
& Bio-fertilizer & 4.31 & 4.08 & $4.20^{\mathrm{A}}$ \\
\cline { 2 - 4 } & Mineral & $4.26^{\mathrm{A}}$ & $4.01^{\mathrm{B}}$ & 4.14 \\
\hline
\end{tabular}

$\overline{\mathrm{a}, \mathrm{b}, \mathrm{c}, \mathrm{A}, \mathrm{B}}$ Means noted with the same letter in column and verse are not significantly different $(p<0.05)$.

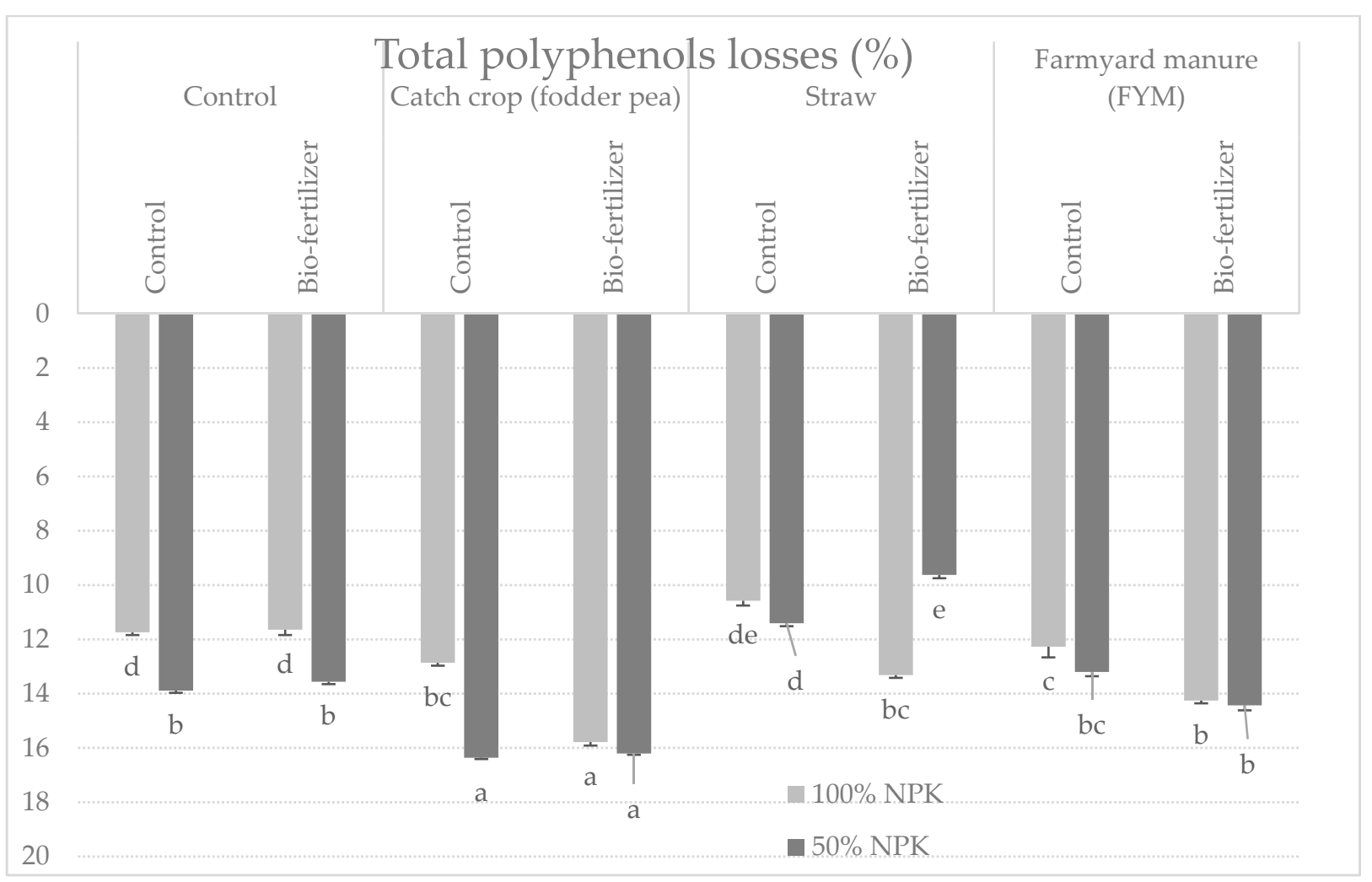

Figure 2. Percentage changes in total polyphenols content in potato tubers after 6 months of storage depending on the tested factors (mean from 3 years storage seasons). a, b, c, d . . : means noted with the same letter are not significantly different $(p<0.05)$. 
Table 7. Chlorogenic acid content in potato tubers after harvest depending on the applied research factors $\left(\mathrm{g} \cdot \mathrm{kg}^{-1} \mathrm{DM}\right)$ (mean from 3 years).

\begin{tabular}{ccccc}
\hline \multirow{2}{*}{$\begin{array}{c}\text { Type of Organic } \\
\text { Fertilizer }\end{array}$} & Bio-Fertilizer Application & \multicolumn{2}{c}{$\begin{array}{c}\text { Mineral } \\
\text { NPK Fertilization }\end{array}$} & Mean \\
\cline { 2 - 4 } & & $\mathbf{1 0 0} \%$ & $\mathbf{5 0 \%}$ & \\
\hline \multirow{2}{*}{ Control } & Control & $3.42 \pm 0.01$ & $2.88 \pm 0.02$ & 3.15 \\
& Bio-fertilizer & $2.95 \pm 0.02$ & $2.92 \pm 0.02$ & 2.93 \\
\hline Catch crop & Control & $4.48 \pm 0.01$ & $3.81 \pm 0.03$ & 4.15 \\
(fodder pea) & Bio-fertilizer & $4.35 \pm 0.01$ & $3.50 \pm 0.01$ & 3.93 \\
\hline \multirow{2}{*}{ Straw } & Control & $3.37 \pm 0.01$ & $2.83 \pm 0.01$ & 3.10 \\
& Bio-fertilizer & $3.33 \pm 0.01$ & $3.28 \pm 0.01$ & 3.31 \\
\hline Farmyard & Control & $3.51 \pm 0.01$ & $3.26 \pm 0.01$ & 3.38 \\
manure (FYM) & Bio-fertilizer & $3.77 \pm 0.01$ & $3.83 \pm 0.01$ & 3.80 \\
\hline \multirow{2}{*}{ Mean } & Control & 3.19 & 2.90 & $3.044^{\mathrm{d}}$ \\
& Catch crop (fodder pea) & 4.42 & 3.66 & $4.04^{\mathrm{a}}$ \\
& Straw & 3.35 & 3.06 & $3.20^{\mathrm{c}}$ \\
& Farmyard manure (FYM) & 3.64 & 3.54 & $3.59^{\mathrm{b}}$ \\
\cline { 2 - 4 } & Control & 3.70 & 3.19 & $3.45^{\mathrm{A}}$ \\
& Bio-fertilizer & 3.60 & 3.38 & $3.49^{\mathrm{A}}$ \\
& Mineral & $3.65 \mathrm{~A}$ & $3.29 \mathrm{~A}$ & 3.47 \\
\hline
\end{tabular}

$\bar{a}, b, c, d, A$, Means noted with the same letter in column and verse are not significantly different $(p<0.05)$.

Table 8. Chlorogenic acid content in potato tubers depending on the applied research factors after 6 months of storage $\left(\mathrm{g} \cdot \mathrm{kg}^{-1} \mathrm{DM}\right)$ (mean from 3 years).

\begin{tabular}{ccccc}
\hline \multirow{2}{*}{$\begin{array}{c}\text { Type of Organic } \\
\text { Fertilizer }\end{array}$} & Bio-Fertilizer Application & \multicolumn{2}{c}{$\begin{array}{c}\text { Mineral } \\
\text { NPK Fertilization }\end{array}$} & Mean \\
\cline { 2 - 4 } & & $\mathbf{1 0 0 \%}$ & $\mathbf{5 0 \%}$ & \\
\hline \multirow{2}{*}{ Control } & Control & $2.98 \pm 0.01$ & $2.44 \pm 0.02$ & 2.71 \\
& Bio-fertilizer & $2.39 \pm 0.01$ & $2.29 \pm 0.01$ & 2.34 \\
\hline Catch crop & Control & $3.55 \pm 0.01$ & $3.32 \pm 0.01$ & 3.44 \\
(fodder pea) & Bio-fertilizer & $3.50 \pm 0.01$ & $3.21 \pm 0.01$ & 3.36 \\
\hline \multirow{2}{*}{ Straw } & Control & $2.87 \pm 0.01$ & $2.54 \pm 0.01$ & 2.71 \\
& Bio-fertilizer & $2.81 \pm 0.01$ & $2.84 \pm 0.01$ & 2.83 \\
\hline Farmyard & Control & $3.18 \pm 0.01$ & $3.14 \pm 0.01$ & 3.16 \\
manure (FYM) & Bio-fertilizer & $3.49 \pm 0.01$ & $3.67 \pm 0.01$ & 3.58 \\
\hline \multirow{2}{*}{ Mean } & Control & 2.69 & 2.37 & $2.53^{\mathrm{c}}$ \\
& Catch crop (fodder pea) & 3.53 & 3.27 & $3.40^{\mathrm{a}}$ \\
& Straw & 2.84 & 2.69 & $2.77^{\mathrm{b}}$ \\
& Farmyard manure (FYM) & 3.34 & 3.41 & $3.37^{\mathrm{a}}$ \\
\cline { 2 - 4 } & Control & 3.15 & 2.86 & $3.00^{\mathrm{A}}$ \\
& Bio-fertilizer & 3.05 & 3.00 & $3.03^{\mathrm{A}}$ \\
& Mineral & $3.10^{\mathrm{A}}$ & $2.93^{\mathrm{A}}$ & 3.01 \\
\hline & NPK Fertilization & & \\
\hline
\end{tabular}

$\mathrm{a}, \mathrm{b}, \mathrm{c}, \mathrm{A}$, Means noted with the same letter in column are not significantly different $(p<0.05)$. 


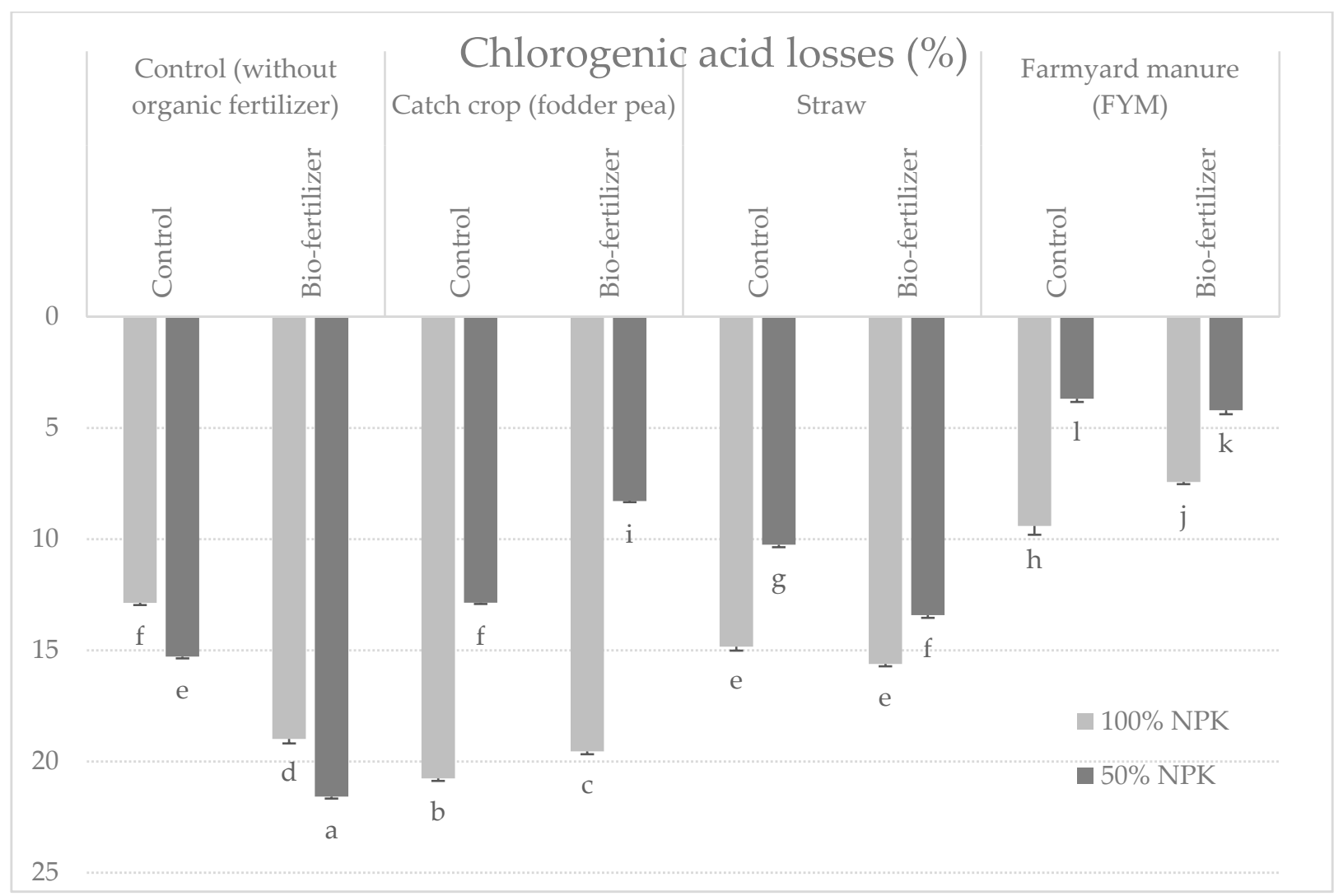

Figure 3. Percentage changes in chlorogenic acid content in potato tubers after 6 months of storage depending on the tested factors (mean from 3 years storage seasons). a, b, c, d . . : means noted with the same letter are not significantly different $(p<0.05)$.

\subsection{Antioxidant Capacity (FRAP) in Potato Tubers after Harvest and after 6 Months of Storage}

All the study factors and their mutual influence significantly differentiated the antioxidant capacity of tubers tested after harvest, measured with the FRAP method (Tables 1 and 9). The highest post-harvest antioxidant activity was characteristic of tubers from plots fertilized with manure, with a full dose of mineral fertilization and biofertilizer $(9.91 \mathrm{mmol}$ $\mathrm{Fe}^{2+} \cdot \mathrm{kg}^{-1}$ ), and the lowest—significantly by tubers from control plots with half the dose of mineral fertilizer. During the 6 months of storage, there was a decrease in antioxidant capacity, on average $12.4 \%$ for the objects (Figure 4 ), and the highest in tubers fertilized with manure, with a full dose of mineral fertilization (15\%). Nevertheless, in tubers from this facility, additionally fertilized with biofertilizer, the highest antioxidant capacity was recorded after 6 months of storage $\left(8.14 \mathrm{mmol} \mathrm{Fe}{ }^{2+} \cdot \mathrm{kg}^{-1}\right)$ (Table 10). All the examined factors and their mutual correlation had a highly significant influence on the examined trait of tubers (Table 1). Moreover, the storage time had a significant effect on the antioxidant capacity, causing its reduction in all the studied objects (Table 3). 
Table 9. Antioxidant capacity (FRAP) in potato tubers after harvest depending on the applied research factors $\left(\mathrm{mmol} \mathrm{Fe}{ }^{2+} \cdot \mathrm{kg}^{-1}\right)$ (mean from 3 years).

\begin{tabular}{|c|c|c|c|c|}
\hline \multirow{2}{*}{$\begin{array}{c}\text { Type of Organic } \\
\text { Fertilizer }\end{array}$} & \multirow[t]{2}{*}{ Bio-Fertilizer Application } & \multicolumn{2}{|c|}{$\begin{array}{c}\text { Mineral } \\
\text { NPK Fertilization }\end{array}$} & \multirow[t]{2}{*}{ Mean } \\
\hline & & $100 \%$ & $50 \%$ & \\
\hline \multirow[b]{2}{*}{ Control } & Control & $7.54 \pm 0.01$ & $6.98 \pm 0.02$ & 7.26 \\
\hline & Bio-fertilizer & $8.98 \pm 0.02$ & $8.02 \pm 0.02$ & 8.50 \\
\hline \multirow{2}{*}{$\begin{array}{l}\text { Catch crop } \\
\text { (fodder pea) }\end{array}$} & & $7.98 \pm 0.01$ & $7.59 \pm 0.03$ & 7.79 \\
\hline & Bio-fertilizer & $8.21 \pm 0.03$ & $8.03 \pm 0.01$ & 8.12 \\
\hline \multirow{2}{*}{ Straw } & Control & $7.64 \pm 0.03$ & $7.51 \pm 0.01$ & 7.58 \\
\hline & Bio-fertilizer & $7.89 \pm 0.01$ & $7.59 \pm 0.04$ & 7.74 \\
\hline \multirow{2}{*}{$\begin{array}{c}\text { Farmyard } \\
\text { manure (FYM) }\end{array}$} & Control & $9.25 \pm 0.04$ & $8.59 \pm 0.05$ & 8.92 \\
\hline & Bio-fertilizer & $9.91 \pm 0.04$ & $9.02 \pm 0.06$ & 9.47 \\
\hline \multirow{7}{*}{ Mean } & Control & 7.67 & 7.89 & $7.89^{\mathrm{B}}$ \\
\hline & Bio-fertilizer & 8.17 & 8.46 & $8.46^{\mathrm{A}}$ \\
\hline & Control & 8.26 & 8.26 & $7.50^{\mathrm{cd}}$ \\
\hline & Catch crop (fodder pea) & 8.10 & 7.81 & $7.95^{b}$ \\
\hline & Straw & 7.77 & 7.55 & $7.66^{c}$ \\
\hline & Farmyard manure (FYM) & 9.58 & 8.81 & $9.19^{a}$ \\
\hline & $\begin{array}{c}\text { Mineral } \\
\text { NPK Fertilization }\end{array}$ & $8.43^{\mathrm{A}}$ & $7.92^{\mathrm{B}}$ & 8.17 \\
\hline
\end{tabular}

$\bar{a}, b, c, d, A, B$ Means noted with the same letter in column and verse are not significantly different $(p<0.05)$.

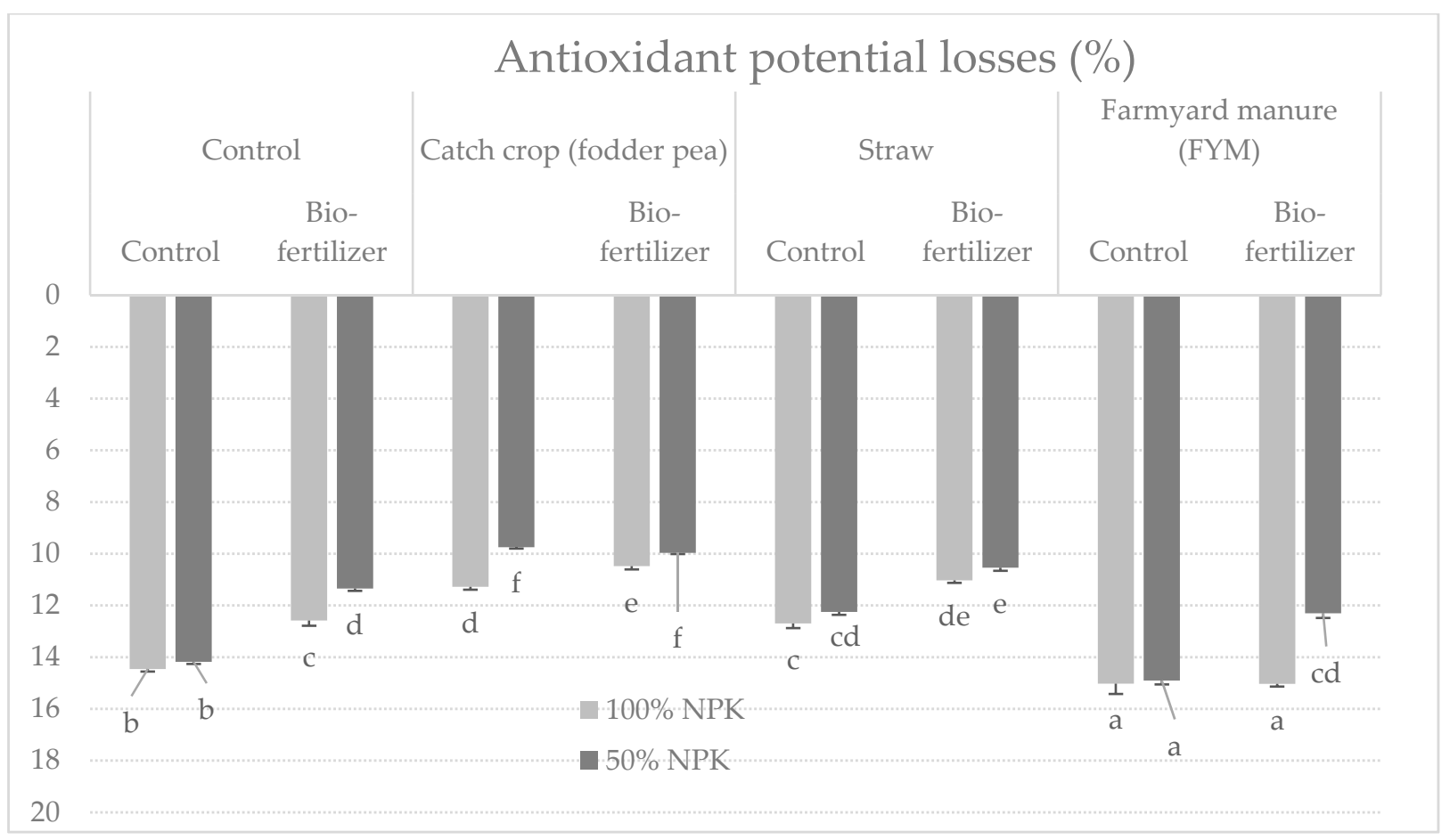

Figure 4. Percentage changes in antioxidant potential FRAP in potato tubers after 6 months of storage depending on the tested factors (mean from 3 years storage seasons). a, b, c, d . . : means noted with the same letter are not significantly different $(p<0.05)$. 
Table 10. Antioxidant capacity (FRAP) in potato tubers after 6 months of storage depending on the applied research factors $\left(\mathrm{mmol} \mathrm{Fe}{ }^{2+} \cdot \mathrm{kg}^{-1}\right)$ (mean from 3 years).

\begin{tabular}{|c|c|c|c|c|}
\hline \multirow{2}{*}{$\begin{array}{c}\text { Type of Organic } \\
\text { Fertilizer }\end{array}$} & \multirow[t]{2}{*}{ Bio-Fertilizer Application } & \multicolumn{2}{|c|}{$\begin{array}{c}\text { Mineral } \\
\text { NPK Fertilization }\end{array}$} & \multirow[t]{2}{*}{ Mean } \\
\hline & & $100 \%$ & $50 \%$ & \\
\hline \multirow{2}{*}{ Control } & Control & $6.45 \pm 0.02$ & $5.99 \pm 0.04$ & 6.22 \\
\hline & Bio-fertilizer & $7.85 \pm 0.01$ & $7.11 \pm 0.06$ & 7.48 \\
\hline \multirow{2}{*}{$\begin{array}{l}\text { Catch crop } \\
\text { (fodder pea) }\end{array}$} & & $7.08 \pm 0.01$ & $6.85 \pm 0.02$ & 6.97 \\
\hline & Bio-fertilizer & $7.35 \pm 0.04$ & $7.23 \pm 0.05$ & 7.29 \\
\hline \multirow{2}{*}{ Straw } & Control & $6.67 \pm 0.05$ & $6.59 \pm 0.05$ & 6.63 \\
\hline & Bio-fertilizer & $7.02 \pm 0.04$ & $6.79 \pm 0.06$ & 6.91 \\
\hline \multirow{2}{*}{$\begin{array}{c}\text { Farmyard } \\
\text { manure (FYM) }\end{array}$} & Control & $7.86 \pm 0.05$ & $7.31 \pm 0.06$ & 7.59 \\
\hline & Bio-fertilizer & $8.42 \pm 0.01$ & $7.91 \pm 0.04$ & 8.17 \\
\hline \multirow{7}{*}{ Mean } & Control & 7.15 & 6.55 & $6.85^{\mathrm{cd}}$ \\
\hline & Catch crop (fodder pea) & 7.22 & 7.04 & $7.13^{b}$ \\
\hline & Straw & 6.85 & 6.69 & $6.77^{\mathrm{d}}$ \\
\hline & Farmyard manure (FYM) & 8.14 & 7.61 & $7.88^{a}$ \\
\hline & Control & 7.02 & 6.69 & $6.85^{B}$ \\
\hline & Bio-fertilizer & 7.66 & 7.26 & $7.46^{\mathrm{A}}$ \\
\hline & $\begin{array}{c}\text { Mineral } \\
\text { NPK Fertilization }\end{array}$ & $7.34^{\mathrm{A}}$ & $6.97^{\mathrm{B}}$ & 7.16 \\
\hline
\end{tabular}

a, b, c, d, A, B Means noted with the same letter in column and verse are not significantly different $(p<0.05)$.

\subsection{Total Amino Acids in Potato Tubers after Harvest and after 6 Months of Storage}

Taking into account the organic fertilization and storage on the amino acids composition of potato tubers after 6 months of storage, the threonine and valine concentration and total amino acids did not change significantly (Table 11). Mineral fertilization, the full dose of NPK fertilization, caused a significant increase in the content of tyrosine, threonine and total AA $(p \leq 0.05)$, as well as a significant decrease in leucine and an increase in aspartic acid, asparagine, and alanine $(p \leq 0.01)$ in potato tubers examined after harvest (Table 12). The content of the remaining amino acids in the tubers examined after the harvest did not depend on the dose of mineral fertilization. After storage, the changes in amino acid content were significant at $(p \leq 0.01)$ for phenylalanine aspartic acid, asparagine, where at the full dose of the mineral fertilizer, the potato tubers contained more than half the dose, significant at $(p \leq 0.05)$ for the other tested amino acids (Table 12). In the case of leucine, the reduced dose of mineral fertilizer increased it, while the content of other amino acids was higher in tubers tested after 6 months of storage from plots with a full dose of mineral fertilization (NPK). The storage time caused a significant $(p \leq 0.01)$ increase in the content of tyrosine, leucine, lysine, alanine, glutamic acid, and total AA, and also (with $p \leq 0.05$ ) of methionine, aspartic acid, and asparagine, while the content of isoleucine, phenyl-alanine decreased at $(p \leq 0.01)$ after tuber storage. Insignificant changes in terms of the content of threonine and valine were recorded in the tested tubers after storage in relation to their content after harvest. With regard to bio-fertilizer and storage (Table 13), bio-fertilizer increased composition of AA. There were no significant effects after storage differences with respect to after harvest values for concentration of threonine and valine. 
Table 11. Effect of organic fertilization and storage on the amino acid composition of potato tubers (g $100 \mathrm{~g}^{-1}$ protein) (mean from 3 years).

\begin{tabular}{|c|c|c|c|c|c|c|c|c|c|c|c|}
\hline \multirow{2}{*}{$\begin{array}{l}\text { Amino } \\
\text { Acids }\end{array}$} & \multicolumn{4}{|c|}{ Before Storage } & \multirow{2}{*}{$\begin{array}{l}\text { Between } \\
\text { Fertilizers }\end{array}$} & \multicolumn{4}{|c|}{ After 6 Months of Storage } & \multirow{2}{*}{$\begin{array}{l}\text { Between } \\
\text { Fertilizers }\end{array}$} & \multirow{2}{*}{$\begin{array}{l}\text { Between } \\
\text { Storages }\end{array}$} \\
\hline & Control & $\begin{array}{c}\text { Catch } \\
\text { Crop (pea) }\end{array}$ & Straw & FYM & & Control & $\begin{array}{c}\text { Catch } \\
\text { Crop (pea) }\end{array}$ & Straw & FYM & & \\
\hline Tyrosine & 0.72 & 1.22 & 1.16 & 1.39 & * & 0.88 & 1.48 & 1.40 & 1.62 & $* *$ & $* *(+)$ \\
\hline Threonine & 1.32 & 3.00 & 2.96 & 1.58 & $*$ & 1.30 & 2.96 & 2.91 & 1.52 & $* *$ & n.s. \\
\hline Methionine & 2.23 & 2.82 & 2.34 & 1.97 & ** & 2.00 & 2.47 & 2.06 & 1.78 & $* *$ & $* *(+)$ \\
\hline Valine & 2.39 & 3.86 & 2.84 & 3.31 & $* *$ & 2.43 & 3.87 & 2.82 & 3.28 & $* *$ & n.s. \\
\hline Isoleucine & 1.76 & 3.36 & 3.25 & 2.92 & $* *$ & 1.68 & 3.13 & 3.10 & 2.66 & $* *$ & $* *(-)$ \\
\hline Leucine & 1.71 & 4.54 & 3.83 & 3.31 & $*$ & 1.93 & 4.75 & 4.27 & 0.85 & $* *$ & $* *(+)$ \\
\hline Lysine & 0.25 & 0.44 & 0.61 & 0.12 & ** & 0.72 & 0.69 & 0.85 & 0.31 & $* *$ & $* *(+)$ \\
\hline Phenyl-alanine & 1.49 & 2.25 & 2.11 & 1.95 & $* *$ & 1.19 & 2.02 & 1.83 & 1.68 & ** & $*(-)$ \\
\hline Aspartic acid & 6.37 & 6.93 & 7.71 & 5.81 & $* *$ & 6.93 & 7.49 & 8.31 & 6.46 & $* *$ & $* *(+)$ \\
\hline Asparagine & 5.43 & 3.93 & 3.79 & 2.79 & $* *$ & 5.95 & 4.41 & 4.21 & 3.17 & $* *$ & $* *(-)$ \\
\hline Alanine & 0.57 & 1.16 & 0.93 & 0.33 & ** & 1.23 & 2.27 & 1.60 & 0.63 & $* *$ & $* *(+)$ \\
\hline Glutamic acid & 5.49 & 7.82 & 6.01 & 4.50 & $* *$ & 6.05 & 8.39 & 6.51 & 4.98 & $* *$ & $* *(+)$ \\
\hline Total AA & 29.73 & 41.33 & 37.54 & 29.98 & ** & 32.29 & 43.93 & 39.87 & 28.94 & $* *$ & n.s. \\
\hline
\end{tabular}

${ }^{*}$ significant difference $p \leq 0.05 ;{ }^{* *}$ significant difference $p \leq 0.01$; n.s.-non-significant difference.

Table 12. Effect of mineral fertilization and storage on the amino acid composition of potato tubers (g $100 \mathrm{~g}^{-1}$ protein) (mean from 3 years).

\begin{tabular}{|c|c|c|c|c|c|c|c|}
\hline \multirow[b]{2}{*}{$\begin{array}{l}\text { Amino } \\
\text { Acids }\end{array}$} & \multicolumn{2}{|c|}{ Before Storage } & \multirow[b]{2}{*}{$\begin{array}{c}\text { Between Mineral } \\
\text { Fertilizers }\end{array}$} & \multicolumn{2}{|c|}{ After 6 Months of Storage } & \multirow[b]{2}{*}{$\begin{array}{l}\text { Between Mineral } \\
\text { Fertilizers }\end{array}$} & \multirow{2}{*}{$\begin{array}{l}\text { Between } \\
\text { Storages }\end{array}$} \\
\hline & $\begin{array}{l}100 \% \\
\text { NPK }\end{array}$ & $\begin{array}{l}50 \% \\
\text { NPK }\end{array}$ & & $\begin{array}{l}100 \% \\
\text { NPK }\end{array}$ & $\begin{array}{c}50 \% \\
\text { NPK }\end{array}$ & & \\
\hline Tyrosine & 1.13 & 1.06 & * & 1.36 & 1.26 & * & $* *(+)$ \\
\hline Threonine & 2.26 & 2.07 & * & 2.21 & 2.02 & * & n.s. \\
\hline Methionine & 2.36 & 2.35 & n.s. & 2.13 & 2.01 & * & $*(+)$ \\
\hline Valine & 3.09 & 3.06 & n.s. & 3.11 & 3.02 & * & n.s. \\
\hline Isoleucine & 2.78 & 2.76 & n.s. & 2.65 & 2.52 & * & $* *(-)$ \\
\hline Leucine & 3.06 & 3.32 & $* *$ & 3.33 & 3.69 & * & $* *(+)$ \\
\hline Lysine & 0.4 & 0.38 & n.s. & 0.69 & 0.57 & * & $* *(+)$ \\
\hline Phenyl-alanine & 2.05 & 2.02 & n.s. & 1.74 & 1.56 & $* *$ & $* *(-)$ \\
\hline Aspartic acid & 7.12 & 6.20 & $* *$ & 7.8 & 6.69 & $* *$ & $*(+)$ \\
\hline Asparagine & 4.57 & 3.67 & $* *$ & 4.98 & 3.78 & $* *$ & $*(+)$ \\
\hline Alanine & 0.87 & 0.65 & $* *$ & 1.59 & 1.12 & * & $* *(+)$ \\
\hline Glutamic acid & 6.04 & 6.02 & n.s. & 6.63 & 6.05 & * & $* *(+)$ \\
\hline Total AA & 35.73 & 33.56 & * & 35.73 & 34.29 & * & $* *(+)$ \\
\hline
\end{tabular}

* significant difference $p \leq 0.05$; ${ }^{* *}$ significant difference $p \leq 0.01$; n.s.--non-significant difference. 
Table 13. Effect of bio-fertilizer and storage on the amino acid composition of potato tubers ( $\mathrm{g} 100 \mathrm{~g}^{-1}$ protein) (mean from 3 years).

\begin{tabular}{|c|c|c|c|c|c|c|c|}
\hline \multirow{2}{*}{$\begin{array}{l}\text { Amino } \\
\text { Acids }\end{array}$} & \multicolumn{2}{|c|}{ Before Storage } & \multirow{2}{*}{$\begin{array}{l}\text { Between without } \\
\text { and with Bio- } \\
\text { Fertilizer }\end{array}$} & \multicolumn{2}{|c|}{$\begin{array}{c}\text { After } 6 \text { Months } \\
\text { of Storage }\end{array}$} & \multirow{2}{*}{$\begin{array}{c}\text { Between without } \\
\text { and with Bio- } \\
\text { Fertilizer }\end{array}$} & \multirow{2}{*}{$\begin{array}{l}\text { Between } \\
\text { Storages }\end{array}$} \\
\hline & Control & Bio-Fertilizer & & Control & Bio-Fertilizer & & \\
\hline Tyrosine & 1.09 & 1.16 & * & 1.28 & 1.41 & * & $* *(+)$ \\
\hline Threonine & 1.78 & 2.65 & * & 1.73 & 2.61 & $* *$ & n.s. \\
\hline Methionine & 2.25 & 2.43 & $* *$ & 1.99 & 2.16 & * & * \\
\hline Valine & 3.00 & 3.20 & $* *$ & 3.01 & 3.19 & * & n.s. \\
\hline Isoleucine & 2.51 & 3.13 & $* *$ & 2.38 & 2.91 & $* *$ & * \\
\hline Leucine & 3.24 & 3.44 & $* *$ & 3.51 & 3.84 & $*$ & $* *$ \\
\hline Lysine & 0.18 & 0.53 & $* *$ & 0.48 & 0.81 & $* *$ & $* *$ \\
\hline $\begin{array}{l}\text { Phenyl- } \\
\text { alanine }\end{array}$ & 1.93 & 1.97 & * & 1.64 & 1.72 & * & $* *$ \\
\hline Aspartic acid & 5.47 & 7.94 & $* *$ & 6.09 & 8.50 & $* *$ & $* *$ \\
\hline Asparagine & 3.74 & 4.23 & $* *$ & 4.25 & 4.58 & * & $* *$ \\
\hline Alanine & 0.46 & 1.03 & $* *$ & 0.91 & 1.56 & $* *$ & $* *$ \\
\hline $\begin{array}{l}\text { Glutamic } \\
\text { acid }\end{array}$ & 4.87 & 7.08 & $* *$ & 5.48 & 6.48 & $* *$ & $* *$ \\
\hline Total AA & 30.52 & 38.79 & $* *$ & 35.73 & 39.77 & $* *$ & $* *$ \\
\hline
\end{tabular}

\section{Discussion}

Edible potato tubers (Solanum tuberosum L.) are a valuable source of many essential nutrients, such as dry matter, starch, and vitamin C, as well as sugars, which also influence the culinary quality features, such as flesh color, palatability, culinary type, and flesh darkening in raw and cooked tubers [8,9,9,46-49]. Moreover, in recent years, it has been recognized that plant peptides and whole proteins have antioxidant properties [50]. The nutritional value of potato protein is comparable to the nutritional value of hen egg white and it exceeds the quality of proteins of other plants [8,51,52]. Potato protein is rich in essential amino acids, such as lysine, leucine, phenylalanine, and threonine, which the human body cannot synthesize. Of the eight amino acids that need to be supplied to the body, as many as seven are found in potato protein [51,53,54]. The American Society for Potato Research has recognized the potato as a gluten-free food with excellent protein quality, offering a number of possibilities for its use. The main benefits of using potato protein are no allergens, better texture, and better nutrition [51]. According to Pęksa [53], the total protein content in potatoes is $1.5-2.3 \%$ of fresh weight, of which the specific protein defined as "pure" constitutes $35-65 \%$. Compared to legumes, especially peas, which contain $9.01 \mathrm{~g}$ per $100 \mathrm{~g}$ of product [29], the protein content in potato tubers is low. However, due to the consumption of potato tubers, it can be a source of proteins with the desired amino acid composition, especially for vegans. In the studies by Wierzbicka and Trawczyński [54], the protein content was within the range of 7.54-11.37\%, and according to Zarzecka and Gugała [55], from 9.54 to $10.19 \%$ of dry weight. In own research, the protein content was at the level of 99.1 and $114.4 \mathrm{~g} \mathrm{~kg}^{-1} \mathrm{DM}$. The highest content of crude protein in potato tubers was found after the combined use of green fertilizer (fodder peas) with a full dose of nitrogen, phosphorus, and potassium (NPK) and biological fertilizer. Comparing the content of crude protein in tubers from plots where half the dose of mineral fertilization was applied, the use of bio-fertilizer increased the content of this component, especially after using straw. Both fodder peas and straw increase the productivity of the soil and its fertility. The introduction of selected strains of microorganisms into the soil may improve 
its microbiological activity, accelerate the decomposition of organic matter, and change its physical properties $[31,36]$, and thus allow the mobilization of nutrients necessary for plant development, influencing not only the yield, but also its quality and health $[39,48-57]$.

The storage time resulted in the reduction of the protein content in potato tubers, and the losses in comparison to other tested bioactive ingredients in tubers were quite small. The highest losses were recorded in tubers from plots fertilized with half the dose of NPK, without the use of organic fertilizers and biofertilizer, and they amounted to $9.06 \%$, and the lowest losses occurred in tubers fertilized with manure with a full dose of mineral fertilizers and the applied bio-fertilizer-1.44\%. In the studies by Černa and Kračmar [58], the content of crude protein at the beginning of storage ranged from $8.9-11.9 \% 100 \% \mathrm{DM}$ and longer storage (16 weeks) reduced the content of total amino acids and crude protein by 35 and $18 \%$, but this was dependent on the variety. In our own research, the storage time increased the content of tyrosine, leucine, lysine, alanine, glutamic acid, and total AA, as well as methionine, aspartic acid, and asparagine, while the content of isoleucine and phenyl-alanine decreased. Insignificant changes in terms of the content of threonine and valine were recorded in the tested tubers after storage in relation to their content after harvest. According to Černa and Kračmar [59], after 16 weeks of potato storage, the amount of total amino acids decreased by about $20 \%$ and it depended on the variety.

In the studies of Brierley et al. [60,61], the increase in free amino acid content occurred during the later storage period and may have been due to an increase in proteinase activity. The increased enzymatic activity was probably due to the synthesis of proteinases, in particular aspartic proteinase, which showed a clear substrate specificity for endogenous tuber proteins [60]. Accumulation of asparagine and glutamine occurred during long storage, which coincided with an increase in proteinase activity [61], which may also explain the results of our own research, where increased levels of these amino acids were obtained after the 6-month storage period of potato tubers.

Dietary potatoes are also an important source of polyphenols, referred to as secondary antioxidant metabolites [62]. They have a pro-health effect, mainly in the prevention of cardiovascular diseases $[63,64]$. Some studies also demonstrate their role in the prevention of cancer $[23,65,66]$ and neurodegenerative diseases [67]. The presence of these compounds in food and antioxidant vitamins influences the antioxidant potential of food, which is an additional protection of the body against the effects of an excessive number of free radicals accumulated as a result of oxidative stress. Occurring in plants, they increase their tolerance to harmful environmental stimuli, especially to drought. Moreover, their presence makes plants less susceptible to pathogens and the occurrence of pests $[68,69]$. The content of polyphenols in the studies by Zarzecka and Gugała [70] ranged from $172.2-177.3 \mathrm{mg} \cdot \mathrm{kg}^{-1}$, Hamouz et al. [71] 62.6-1157.0 $\mathrm{mg} \mathrm{kg}^{-1}$, Lemos et al. [72], $209.1 \mathrm{mg} \cdot \mathrm{kg}^{-1}$ fresh weight of tubers. Reyes et al. [73] and Hamouz et al. [71] found that the concentration of polyphenols in tubers depended on the variety. Moreover, Hamouz et al. [71] and Reyes et al. [73] showed that the concentration of these compounds was determined by the color of the genotype parenchyma and the location of the tests. In the presented research, the total polyphenol content was $4.12-5.64 \mathrm{~g} \mathrm{~kg}^{-1} \mathrm{DM}$, which with an average content of $24.5 \% \mathrm{DM}$ gives $168-230 \mathrm{mg} \cdot \mathrm{kg}^{-1} \mathrm{FM}$. The highest amount of total polyphenols was obtained in tubers using peas, a full dose of mineral fertilizer and bio-fertilizer, both after harvest and storage. After storage, the content of total polyphenols dropped from 9.6-16.4\%. Gheribi [74] noted that the content of phenolic compounds in food products varies greatly and depends on many factors, including cultivation methods, technological processing, and storage time. In the studies by Lombardo et al. [16,17], the ecological cultivation system produced tubers with an increased content of phenols. They also found that the differences in the polyphenol content in tubers depended on the cultivar and the year of the study. In the studies by Mystkowska et al. [75], the applied biostimulants significantly increased the polyphenol content in tubers, similar to the authors' own research. The polyphenol content of potatoes can be modified by growing conditions, farming system, and nutrient supply [76,77]. 
Chlorogenic acid accounts for 49.3-61.0\% [78] or even up to 90\% [79] of the total phenolics in potato tubers, most of the discussion focuses on this relationship [80]. For this reason, chlorogenic acid has many beneficial properties for human health, such as being antioxidant, anti-cancer, anti-inflammatory, analgesic, antimicrobial, neuroprotective, and cardioprotective $[62,81,82]$. In the authors' own research, the content of chlorogenic acid was $2.88-4.48 \mathrm{~g} \cdot \mathrm{kg}^{-1} \mathrm{DM}$, the highest concentration was found in samples from plots with the use of organic matter-peas. As measured by other researchers, André et al.'s [62] CGA concentrations ranged from 140 to $2740 \mathrm{mg} / 100 \mathrm{~g}$ dry weight (DW), Furrer et al. [83] reported values from 43 to $953 \mathrm{mg} / 100 \mathrm{~g}$ DW, values of Valiñas et al. [84] ranged from 3.5 to $73.4 \mathrm{mg} / \mathrm{kg} \mathrm{FW}$, and Galani et al. [14] found levels of 6.0 to $28.9 \mathrm{mg} / \mathrm{kg}$ of FW. The results show a significant influence of genotype on CAC. In studies by Orsák et al. [85], cold storage $\left(4{ }^{\circ} \mathrm{C}\right)$ for six months resulted in a significant increase in CAC compared to post-harvest levels, an average of $87.5 \%$ for all flesh-colored varieties assessed. On the other hand, the yellow skin and flesh of Agria did not show such a storage effect on the CAC (ambiguous difference to the post-harvest CAC). Higher storage temperatures, however, can reverse this tendency and result in an unchanged or reduced content of phenolic compounds as described by André et al. [58]. In the authors' own research, the content of chlorogenic acid decreased on average for objects by $13.06 \%$.

The antioxidant capacity of potato tubers is influenced, among others, by polyphenols, the most important of which are flavonoids. Most of them are found in plant tissues, whose defense system against free radicals works very well. Other antioxidants found in nature are also lignans, vitamins $\mathrm{A}, \mathrm{C}$, and $\mathrm{E}$, melatonin, glutathione, $\beta$-carotene, bilirubin, uric acid, carnitine, and ferulic acid. In our own research, the ferric ion reducing antioxidant power ranged from 6.98-9.91 mmol Fe ${ }^{2+} \mathrm{kg}^{-1} \mathrm{DM}$. The highest post-harvest antioxidant activity was characteristic of tubers from the plots fertilized with manure, a full dose of mineral fertilization, and bio-fertilizer. During the 6 months of storage, there was a decrease in antioxidant capacity, which could be related to the decrease in the content of polyphenols, but also of vitamin C [32]. Nevertheless, in tubers fertilized with manure, with a full dose of mineral fertilization, additionally fertilized with biofertilizer, the highest antioxidant capacity was recorded after 6 months of storage. All researched factors and their mutual correlation influenced the researched trait of tubers.

\section{Conclusions}

With a growing world population, accelerating climate change, and limited arable land, it is crucial to focus on plant resources for sustainable food production. Potato tubers are rich in secondary metabolites, many of which have strong antioxidant capacity and have beneficial effects on human health. Bio-fertilizers enable more effective absorption of nutrients from the substrate, and thus a better supply of nutrients to plants. The conducted research showed the interactive influence of all tested factors on the assessed bioactive compounds. The use of bio-fertilizer with organic matter introduced into the soil, especially fodder peas, increases the tested nutrients in potato tubers cultivar 'Satina', despite limiting the use of mineral fertilizers. Storage contributed to the loss of the tested ingredients, especially polyphenolic compounds, the content of which influences the antioxidant capacity of tubers. In turn, the storage time increased the content of tyrosine, leucine, lysine, alanine, glutamic acid, and total AA, and also methionine, aspartic acid, and asparagine, while the content of isoleucine and phenyl-alanine decreased. This may be related to an increase in proteinase activity.

The presented research results may be useful in the selection the most valuable fertilizer set, with the possibility of using agricultural crops, e.g., the effect of straw, green manure, or manure on the nutritional value of potato tubers, especially on their content of free amino acids, FRAP, polyphenols, and chlorogenic acid. The use of bio-fertilizer increases the effectiveness of the organic activity fertilizers, allows you to limit the use of mineral fertilizers, and thus gives the opportunity for organic farming. 
Funding: This research was funded by the Polish Ministry Project: "Possibilities for reduction agrotechnical operations in potato production and the nutritional value and health tubers stored under controlled conditions" (Contract nr Grant 0863/B/P01/2009/36). Research work financed by the study in 2009-2012.

Institutional Review Board Statement: Not applicable.

Informed Consent Statement: Not applicable.

Data Availability Statement: Not applicable.

Acknowledgments: I thank the Elke Pawelzik for the opportunity to conduct laboratory tests in Department of Quality Plant Products, Georg August University in Göttingen.

Conflicts of Interest: I declare no conflict of interest.

\section{References}

1. Staniak, M. Sustainable development of rural areas in environmental aspect. Water-Environ.-Rular Areas 2009, 9, 187-194.

2. Mrówczyński, M.; Magdalena Roth, M. Sustainable use of plant protection products. Problems Agricult. Eng. 2009,2 , 93-97. (In Polish)

3. Rutkowska, A.; Pikuła, D. Effect of crop rotation and nitrogen fertilization on the quality and quantity of soil organic matter. Soil Process. Curr. Trends Qual. Assess. 2013, 9, 249-267.

4. FAO. Food and Agriculture Organization of the United Nations. The Future of Food and Agriculture. Alternative Pathways to 2050. 2018. Available online: http://www.fao.org/global-perspectives-studies/resources/detail/en/c/1157074/ (accessed on 1 October 2021).

5. Gustavsen, G.W. Sustainability and Potato Consumption. Potato Res. 2021, 64, 571-586. [CrossRef]

6. Singh, B.; Raigond, P.; Dutt, S.; Kumar, M. Potatoes for Food and Nutritional Security. In Potato; Raigond, P., Singh, B., Dutt, S., Chakrabarti, S.K., Eds.; Springer: Berlin/Heidelberg, Germany, 2020. [CrossRef]

7. Kunachowicz, H.; Nadolna, I.; Iwanow, K.; Przygoda, B. Nutritional Value of Selected Food Products and Typical Dishes; Wyd. Lekarskie PZWL: Warszawa, Poland, 2010. (In Polish)

8. Burlingame, B.; Mouille', B.; Charrondie're, R. Nutrients, bioactive non-nutrients and anti-nutrients in potatoes. J Food Compos. Analy. 2009, 22, 494-502. [CrossRef]

9. Ezekiel, R.; Singh, N.; Sharma, S.; Kaur, A. Beneficial phytochemicals in potato-A review. Food Res. Int. 2013, 50, 487-496. [CrossRef]

10. FAOSTAT, Statistical Database. 2020. Available online: http:/ / faostat.fao.org/ (accessed on 1 October 2021).

11. Gumul, D.; Ziobro, R.; Noga, M.; Sabat, R. Characterisation of five potato cultivars according to their nutritional and pro-health components. Acta Sci. Pol. Technol. Aliment 2011, 10, 73-81.

12. Tsao, R. Phytochemical profiles of potato and their roles in human health and wellness. In Global Science Books Food; Elsevier: Amsterdam, The Netherlands, 2009; pp. 125-135.

13. Reddivari, L.; Hale, A.L.; Miller, J.C. Genotype, location, and year influence antioxidant activity, carotenoid content, phenolic content, and composition in specialty potatoes. J. Agr. Food Chem. 2007, 55, 8073-8079. [CrossRef]

14. Galani, J.H.Y.; Mankad, P.M.; Shah, A.K.; Patel, N.J.; Acharya, R.R.; Talati, J.G. Effect of storage temperature on vitamin C, total phenolics, UPLC phenolic acid profile and antioxidant capacity of eleven potato (Solanum tuberosum) varieties. Hort. Plant J. 2017, 3, 73-89. [CrossRef]

15. Akyol, H.; Riciputi, Y.; Capanoglu, E.; Caboni, M.F.; Verardo, V. Phenolic Compounds in the Potato and Its Byproducts: An Overview. Int. J. Mol. Sci. 2016, 17, 835. [CrossRef] [PubMed]

16. Lombardo, S.; Pandino, G.; Mauromicale, G. The effect on tuber quality of an organic versus a conventional cultivation system in the early crop potato. J. Food Compos. Anal. 2017, 62, 189-196. [CrossRef]

17. Lombardo, S.; Pandino, G.; Mauromicale, G. The influence of growing environment on the antioxidant and mineral content of early crop potato. J. Food Compos. Anal. 2013, 32, 28-35. [CrossRef]

18. Smith-Spangler, C.; Brandeau, M.L.; Hunter, G.E.; Bavinger, J.C.; Pearson, M.; Eschbach, P.J.; Sundaram, V.; Liu, H.; Schirmer, P.; Stave, C.; et al. Are organic foods safer or healthier than conventional alternatives? A systematic review. Ann. Intern. Med. 2012, 157, 348-366. [CrossRef]

19. Beals, K.A. Potatoes, Nutrition and Health. Am. J. Potato Res. 2019, 96, 102-110. [CrossRef]

20. Mangge, H.; Becker, K.; Fuchs, D.; Gostner, J.M. Antioxidants, inflammation and cardiovascular disease. World J. Cardiol. 2014, 6, 462-477. [CrossRef] [PubMed]

21. Camire, M.E.; Kubow, S.; Donnelly, D.J. Potatoes and human health. Crit. Rev. Food Sci. Nutr. 2009, 49, 823-840. [CrossRef]

22. Murr, C.; Winklhofer-Roob, B.M.; Schroecksnadel, K.; Maritschnegg, M.; Mangge, H.; Bo“"hm, B.O.; Winkelmann, B.R.; März, W.; Fuchs, D. Inverse association between serum concentrations of neopterin and antioxidants in patients with and without angiographic coronary artery disease. Atherosclerosis 2009, 202, 543-549. [CrossRef]

23. Friedman, M. Chemistry, Biochemistry, and Dietary Role of Potato Polyphenols. A Review. J. Agric. Food Chem. 1997, 45, 1523-1540. [CrossRef] 
24. Lovat, C.; Nassar, A.M.K.; Kubow, S.; Li, X.-Q.; Donnelly, D.J. Metabolic Biosynthesis of Potato (Solanum tuberosum L.) Antioxidants and Implications for Human Health. Crit. Rev. Food Sci. Nutr. 2016, 56, 2278-2303. [CrossRef]

25. McGill, C.R.; Kurilich, A.C.; Davignon, J. The role of potatoes and potato components in cardiometabolic health: A review. Ann. Med. 2013, 45, 467-473. [CrossRef]

26. Wang, Q.; Chen, Q.; He, M.; Mir, P.; Su, J.; Yang, Q. Inhibitory effect of antioxidant extracts from various potatoes on the proliferation of human colon and liver cancer cells. Nutr. Cancer 2011, 63, 1044-1052. [CrossRef]

27. Willcox, J.K.; Ash, S.L.; Catignani, G.L. Antioxidants and Prevention of Chronic Disease. J. Crit. Rev. Food Sci. Nutr. 2004, 44, 275-295. [CrossRef]

28. Ikanone, C.E.O.; Oyekan, P.O. Effect of Boiling and Frying on the Total Carbohydrate, Vitamin C and Mineral Contents of Irish (Solanun tuberosum) and Sweet (Ipomea batatas) Potato Tubers. Nigerian Food J. 2014, 32, 33-39. [CrossRef]

29. Fabbri, A.D.; Crosby, G.A. A review of the impact of preparation and cooking on the nutritional quality of vegetables and legumes. Intern. J. Gastr. Food Sci. 2016, 3, 2-11. [CrossRef]

30. Trawczyński, C. Nutrient balance in the organic crop production system on the light soil. J. Res. Appl. Agric. Eng. 2010, 55, 166-168. (In Polish)

31. Trawczyński, C.; Bogdanowicz, P. The use of Soil Fertiliser in the aspect of ecological potato cultivation. J. Res. App. Agric. Eng. 2007, 52, 94-97. (In Polish)

32. Pikuła, D. Environmental aspects of managing the organic matter in agriculture. Econ. Reg. Stud. 2015, 8, 98-112.

33. Zydlik, P.; Zydlik, Z. Impact of biological effective microorganisms (EM) preparations on some physico-chemical properties of soil and the vegetative growth of apple-tree rootstocks. Nauka Przyr. Techn. 2008, 2, 1-8.

34. Shah, H.S.; Saleem, M.F.; Shahid, M. Effect of different fertilizers and effective microorganisms on growth, yield and quality of maize. Int. J. Agric. Biol. 2001, 3, 378-379.

35. Kołodziejczyk, M. Effect of nitrogen fertilization and microbial preparations on potato yielding. Plant. Soil Environ. 2014, 60, 379-386. [CrossRef]

36. Długosz, J.; Orzechowski, M.; Piotrowska, A.; Smólczyński, S.; Bogdanowicz, P. Changes in some soil properties under the influence of the soil fertilizer UGmax. Pol. J. Environ. Stud. 2012, 21, 32-34.

37. Jabłoński, K. The effect of new generation multi-component fertilization on potato yield and quality. Zesz. Probl. Post. Nauk Rol. 2006, 511, 309-315.

38. Wichrowska, D.; Wszelaczyńska, E.; Pobereżny, J. Effect of nutrient supply from different sources on some quality parameters of potato tubers. J. Elementol. 2015, 20, 217-230. [CrossRef]

39. Wszelaczynska, E.; Poberezny, J.; Wichrowska, D. Yielding and size of losses after storage of potato (Solanum tuberosum L.) cultivar 'Satina' depending on the farming system and the soil fertilizer application. Fresenius Environ. Bull. 2016, 25, 3159-3168.

40. Wichrowska, D.; Szczepanek, M. Possibility of Limiting Mineral Fertilization in Potato Cultivation by Using Bio-Fertilizer and Its Influence on Protein Content in Potato Tubers. Agriculture 2020, 10, 442. [CrossRef]

41. Sweeney, R.A.; Rexroad, P.R. Comparison of LECO FP-228 "nitrogen determinator" with AOAC copper catalyst Kjeldahl method for crude protein. J. Assoc. O Anal. Chem. 1987, 70, 1028-1030. [CrossRef]

42. Fisher, G.H.; Arias, I.; Quesada, I.; D’Aniello, S.; Errico, F.; Di Fiore, M.M.; D'Aniello, A. A fast and sensitive method for measuring picomole levels of total free amino acids in very small amounts of biological tissues. Amino Acids 2001, 20, 163-173. [CrossRef] [PubMed]

43. Griffiths, D.W.; Bain, H.; Dale, M.F. Development of a rapid colorimetric method for the determination of chlorogenic acid in freeze-dried potato tubers. J. Sci. Food. Agric. 1992, 58, 41-48. [CrossRef]

44. Singleton, V.L.; Orthofer, R. Analysis of total phenols and other oxidation substrates and antioxidants by means of Folin-Ciocalteu reagent. In Methods in ENZYMOLOGY; Abelson, J.N., Simon, M.I., Sies, H., Eds.; Academic Press: Burlington, MA, USA, 1999; Volume 299, pp. 152-178.

45. Benzie, I.F.; Strain, J.J. Ferric reducing/antioxidant power assay: Direct measure of total antioxidant activity of biological fluids and modified version for simultaneous measurement of total antioxidant power and ascorbic acid concentration. Methods Enzymol. 1999, 299, 15-27.

46. Leszczyński, W. Nutrition value of potato and potato products (Review of literature). Biul. IHAR 2012, 266, 5-20. (In Polish)

47. Hassanpanah, D.; Hassanabadi, H.; Azizi Chakherchaman, S.H. Evaluation of Cooking Quality Characteristics of Advanced Clones and Potato Cultivars. Am. J. Food Technol. 2011, 6, 72-79. [CrossRef]

48. Wichrowska, D.; Wojdyła, T.; Rogozińska, I. Concentrations of some macroelements in potato tubers stored at $4{ }^{\circ} \mathrm{C}$ and $8{ }^{\circ} \mathrm{C}$. J. Elementol. 2009, 14, 373-382.

49. Garcia, M.C.; Puchalska, P.; Esteve, C.; Marina, M.L. Vegetable foods: A cheap source of proteins and peptides with antihypertensive, antioxidant, and other less occurrence bioactivities. Talanta 2013, 106, 328-349. [CrossRef] [PubMed]

50. Elfaki, A.E.; Abbsher, A.M. Nutritional situation of potato subjected to Sudanese cooking methods. J. Appl. Sci. Res. 2010, $6,980-984$

51. Harkema, J. Potato Proteins "Free From" Texture \& Nutrition. Proceeding of the Conference Solanic Potato Proteins-Free From Food Expo, Barcelona, Belgium, 4-5 June 2015; Available online: http:/ /www.freefromfoodexpo.com/pdf/2015-conferencesolanic.pdf (accessed on 1 October 2021).

52. Järvan, M.; Edesi, L. The effect of cultivation methods on the yield and biological quality of potato. Agronomy Res. 2009, 7, 289-299.

53. Pęksa, A. Potato protein-Characteristics of properties. Post. Nauk Rol. 2003, 5, 79-94. (In Polish) 
54. Wierzbicka, A.; Trawczyński, C. Factors influencing the content and yield of protein in potato tubers. Biul. IHAR 2012, 266, 181-190. (In Polish)

55. Zarzecka, K.; Gugała, M. The influence of herbicides and their mixtures on total proteins content and proper proteins in potato tubers. Plant Soil Environ. 2005, 51, 517-522. [CrossRef]

56. Kołodziejczyk, M. Effect of nitrogen fertilisation and microbial preparations on quality and storage loses in table potato. Acta Agroph 2016, 23, 67-78.

57. Reddivari, L.; Hale, H.A.; Creighton-Miler, J. Determination of phenolic content, composition and their contribution to antioxidant activity in specialty potato selections. Am. J. Potato Res. 2007, 84, 275-282. [CrossRef]

58. Jeske, M.; Pańka, D.; Wichrowska, D. Effect of chemical protection, organic fertilization and UGmax soil conditioner on health status of potato tubers. Prog. Plant Prot. 2015, 55, 92-97.

59. Černá, M.; Kráčmar, S. The effect of storage on the amino acids composition in potato tubers. Acta Univ. Agric. Silvicult. Mendelianae Brunensis 2010, 58, 49-55.

60. Brierley, E.R.; Bonner, P.L.R.; Cobb, A.H. Factors influencing the free amino acid content of potato (Solanum tuberosum L.) tubers during prolonged storage. J. Sci. Food Agric. 1996, 70, 515-525. [CrossRef]

61. Brierley, E.R.; Bonner, P.L.R.; Cobb, A.H. Aspects of amino acids metabolism in stored potato tubers (cv. Pentland Dell). Plant Sc. 1997, 127, 17-24. [CrossRef]

62. André, C.M.; Schafleitner, R.; Guignard, C.; Oufir, M.; Aliaga, C.A.; Nomberto, G.; Hoffmann, L.; Hausman, J.F.; Evers, D.; Larondelle, Y. Modification of the health-promoting value of potato tubers field grown under drought stress: Emphasis on dietary antioxidant and glycoalkaloid contents in five native andean cul $\neg$ tivars (Solanum tuberosum L.). J. Agricult. Food Chem. 2009, 57, 599-609. [CrossRef] [PubMed]

63. Albishi, T.; John, J.A.; Al-Khalifa, A.S.; Shahidi, F. Phenolic content and antioxidant activities of selected potato varieties and their processing by-products. J. Funct. Foods 2013, 5, 590-600. [CrossRef]

64. Eryigit, T.; Kumlay, A.M.; Yildirim, B. Potato antioxidants: Effect of environmental conditions and agronomical practices. In Proceedings of the 19th Triennial Conference of the European Association for Potato Research EAPR, Brussels, Belgium, 6-11 July 2014; Abstracts Book (appendix). p. 288.

65. Mäder, J.; Rawel, H.; Kroh, L.W. Composition of phenolic compounds and glycoalkaoids $\alpha$-solanine and $\alpha$-chaconine during commercial potato processing. J. Agric. Food. Chem. 2009, 57, 6292-6297. [CrossRef]

66. Manach, C.; Scalbert, A.; Morand, C.; Remesy, C.; Jimenez, L. Polyphenols: Food sources and bioavailability. Am. J. Clin. Nutr. 2004, 79, 727-747. [CrossRef] [PubMed]

67. Poprac, P.; Jomova, K.; Simunkova, M. Targeting free radicals in oxidative stress-related human diseases. Trends Pharmacol. Sci. 2017, 38, 592-607. [CrossRef]

68. Brown, C.R. Antioxidants in potato. Am. J. Pot. Res. 2005, 62, 163-172. [CrossRef]

69. Matysiak, K.; Adamczewski, K.; Kaczmarek, S. The influence of the Asahi SL biostimulator on the yield and selected quantitative and qualitative characteristics of some agricultural plants cultivated in the conditions of Wielkopolska. Prog. Plant Prot. 2011, 51, 1849-1857. (In Polish)

70. Zarzecka, K.; Gugała, M. The effect of herbicides and soil tillage systems on the content of polyphenols in potato tubers. Pol J. Environ. Stud. 2011, 20, 513-517.

71. Hamouz, K.; Lachman, J.; Pazderu, K.; Hejtmankova, K.; Cimr, J.; Musilova, J.; Pivec, V.; Orsak, M.; Svobodova, A. Effect of cultivar, location and method of cultivation on the content of chlorogenic acid in potatoes with different flesh colour. Plant Soil Environ. 2013, 59, 465-471. [CrossRef]

72. Lemos, M.A.; Aliyu, M.M.; Kynoch, G.; Joseph, L.R.; Hungerford, G. Effect of cooking on the levels of bioactive compounds in Purple Majesty Potato. In Proceedings of the Inside Food Symposium, Leuven, Belgium, 9-12 April 2013; pp. 1-6.

73. Reyes, L.F.; Miller, J.C.; Cisneros-Zevallos, L. Environmental conditions influence the content any yield of anthocyanins and total phenolics in purple- and redflesh potatoes during tuber development. Am. J. Potato Res. 2004, 81, 187-193. [CrossRef]

74. Gheribi, E. Importance of polyphenolic compounds from fruits and vegetables in atherosclerosis dietotherapy. Med. Rodz. 2013, 4, 149-153. (In Polish)

75. Mystkowska, I.; Zarzecka, K.; Gugała, M.; Sikorska, A. The Polyphenol Content in Three Edible Potato Cultivars Depending on the Biostimulants Used. Agriculture 2020, 10, 269. [CrossRef]

76. Hajślova, J.; Schulzova, V.; Slanina, P.; Janne, K.; Hellenas, K.E.; Andersson, C.H. Quality of organically and conventionally grown potatoes; Four year study of micronutrients, metals, secondary, metabolites, enzymic browning and organoleptic properties. Food Addit. Contam. 2005, 22, 514-534. [CrossRef] [PubMed]

77. Grudzińska, M.; Czerko, Z.; Zarzyńska, K.; Borowska-Komenda, M. Bioactive Compounds in Potato Tubers: Effects of Farming System, Cooking Method, and Flesh Color. PLoS ONE 2016, 11, e0153980. [CrossRef]

78. Riciputi, Y.; Diaz-de-Cerio, E.; Akyol, H.; Capanoglu, E.; Cerretani, L.; Caboni, M.F.; Verardo, V. Establishment of ultrasoundassisted extraction of phenolic compounds from industrial potato by-products using response surface methodology. Food Chem. 2018, 269, 258-263. [CrossRef] [PubMed]

79. Friedman, M.; Levin, C.E. Analysis and biological activities of potato glycoalkaloids, calystegine alkaloids, phenolic compounds, and anthocyanins. In Advances in Potato Chemistry and Technology; Singh, J., Kaur, L., Eds.; Elsevier-Academic Press: Amsterdam, The Netherlands, 2009; pp. 127-161. 
80. Külen, O.; Stushnoff, C.; Holm, D.G. Effect of cold storage on total phenolics content, antioxidant activity and vitamin C level of selected potato clones. J. Sci. Food Agric. 2013, 93, 2437-2444. [CrossRef]

81. Zarzecka, K.; Gugała, M.; Sikorska, A.; Mystkowska, I.; Baranowska, A.; Niewęgłowski, M.; Dołega, H. The effect of herbicides and biostimulants on polyphenol content of potato (Solanum tuberosum L.) tubers and leaves. J. Saudi Soc. Agric. Sci. 2019, 18, 102-106. [CrossRef]

82. Escuredo, O.; Seijo-Rogríguez, A.; Rodríguez-Flores, M.S.; Míguez, M.; Seijo, M.C. Influence of weather conditions on the physicochemical characteristics of potato tubers. Plant Soil Environ. 2018, 64, 317-323.

83. Furrer, A.; Cladis, D.P.; Kurilich, A.; Manoharan, R.; Ferruzzi, M.G. Changes in phenolic content of commercial potato varieties through industrial processing and fresh preparation. Food Chem. 2017, 218, 47-55. [CrossRef]

84. Valiñas, M.A.; Lanteri, M.L.; Ten Have, A.; Andreu, A.B. Chlorogenic acid, anthocyanin and flavan-3-ol biosynthesis in flesh and skin of Andean potato tubers (Solanum tuberosum subsp. andigena). Food Chem. 2017, 229, 837-846. [CrossRef]

85. Orsák, M.; Hamouz, K.; Lachman, J.; Kasal, P. Chlorogenic acid content in potato tubers with colored flesh as affected by a genotype, location and long-term storage. Plant Soil Environ. 2019, 65, 355-360. [CrossRef] 